\title{
GENETIC BEHAVIOR OF SOME SOYBEAN GENOTYPES UNDER NORMAL AND STRESS IRRIGATION CONDITIONS
}

\author{
F. E. A. Waly \\ Food Legumes Research Department., Field Crops Research Institute., ARC., \\ Giza, Egypt. \\ Received: Feb. 8, 2021 \\ Accepted: Mar. 30, 2021
}

\begin{abstract}
The present study was carried out during 2017 and 2018 seasons at the experimental farm of Agricultural Station of Etay El-Barood, EL-Behira overnorate, Egypt. Six soybeans parental genotypes and their $15 F_{1}$ were evaluated for seed yield and some of its attributes under normal irrigation conditions (irrigate every 15 days) and stress irrigation conditions (irrigate every $\mathbf{3 0}$ days) to select the best genotypes (parents and crosses) had high yield under water stress conditions. Also, to determine the type of gene action involving seed yield and yield components traits and the method of selection for the best crosses in segregation generations under normal and stress irrigations conditions. The results indicated that mean square for genotypes, parents, crosses, parents vs. crosses, genotypes $x$ irrigation, parents $x$ irrigation, F1 $x$ irrigation and parents $\mathrm{x} F 1 \mathrm{x}$ irrigation were significant for all studied traits under both irrigation treatments and the combined analysis except parents vs. crosses for maturity date under normal irrigation. The two parents D89-8940 and Line162 and the two crosses D89-8940 $x$ Line162 and Dr101 x Line162 recorded the highest seed yield/plant (g) in both irrigation treatments and the combined analysis. Our results indicated that mean square associated with general combining ability (GCA) and specific combining ability (SCA) were significant for all studied traits under normal, stress conditions and combined analysis except SCA for main root length $\mathrm{cm}$ under normal irrigation condition. The highly GCA/SCA ratio more than the unity was observed for all studied traits which may indicate that the largest part of the total genetic variability associated with these traits a result of additive and additive $x$ additive. The parental genotypes D89-8940, Dr101 and Line162 seemed to be excellent combiners for seed yield/plant and most other traits under normal, stress and the combined analysis. The most desirable Sij effects for seed yield/plant were recorded by the cross Dr101 x Line162 flowed by Lkota $\times$ Dr101 and Dr101 x Giza21. It could be recommended to use the pedigree method to select the superior crosses for high yield in the segregation generation under both normal and drought conditions.
\end{abstract}

Key words: Soybean- Stress irrigation- Combining ability.

\section{INTRODUCTION}

Soybean (Glycine max L.) is one of the most important leguminous crops in the world, which is used primarily to produce high quality edible oil, with its dry seeds containing about $20 \%$ oil. Seed components are also used in the animal and poultry feed industry for high protein content of up to $40 \%$ (Singh and Shivakumar, 2010) and Li-Juan and RuZhen (2010). World total soybean production reached about 333.67 million

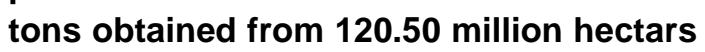
in 2019, while Egypt's soybean production from dry soybean in 2019 reached about 44000 tons obtained from 14000 hectars (FAOSTAT, 2019). Soybeans are exposed to many of the abiotic stresses that affect the growth and productivity of soybeans, such as drought. Drought reduces plant growth by influencing many physiological and 
biochemical processes, such as photosynthesis (Abdalla, (2011) and Azadeh et al., (2014)). Drought reached the top of its negative impact on crops by reducing fresh and dry biomass production as well as yield production (Lisar et al., 2012). Frederick et al., (2001) and Sadeghipour, and Abbasi (2012) in greenhouse and field studies showed that drought stress led to significant reduction in seed yield (24 50\%) from distinct locations and time. Plant breeding programs play a major role in improving the soybean yield under drought conditions. Plant breeding using typical old techniques has proved very handy for the identification of stresstolerant genetic traits in various crops and cultivars and the transfer of those traits into the cultivars having good agronomic performance (Ashraf, (2010)). Pre-knowledge of parents' abilities used in the breeding Program under Drought is one of the most important factors for the success of the breeding program for obtained high yield offspring under drought conditions. The success of a plant breeding program is mostly determined by the selection of desired parents (Farshadfar et al., (2013)) and the combining ability of these parents may determine the ability of these parents for transfer their advantages to their offspring (Hayes and Immer, (1942)). In most breeding programs for abiotic stress such as drought, pre-breeding screening of parents will done by exposed them to laboratory drought conditions such as different concentrations of PEG and measured their ability to tolerate these concentrations through some chemical properties such as the amount of proline and pigments in the leaves, In addition to the plant length, root and shoot length and loss of water content. After identifying the abilities of parents in the laboratory, these traits can be traced in the offspring through some breeding systems such as diallel crosses by estimating the general and specific combining ability. Knowledge of the estimated GCA and SCA as well as gene action is needed at the initial stage of the effort to improve a plant character (Durai and Subbalakshmi, (2010)) in order to identify which combination of parents will produce the desirable offspring (Tan, (2010) and Machikowa et al. (2011)). Diallel crossing analysis is an excellent tool in providing the breeder with the nature and amount of genetic parameter, and the general and specific combining ability of parents and their hybrids, respectively. Through diallel crossing, it is possible to choose a parent and provide information on the GCA of the parent and the SCA of the crossing combination, which helps the breeder to increase/improve and select the segregant population. Specific combining ability and general combining ability also provide information about the type of gene action controlling a trait (Fehr, (1987)). The present study aimed to estimate the combining abilities of parents and their crosses under normal and stress irrigation conditions to determine the best genotypes with high yield and the method of selection will use in segregation generation.

\section{MATERIALS AND METHODS}

A- Pre-breeding screening of parental genotypes:

A laboratory experiment was conducted at Itay EL-Baroud agriculture research station during 2017 summer season. Where, the seeds of the six prenatal genotypes Lakota (P1), Giza82 (P2), D89-8940 (P3), Dr101 (P4), Line162 (P5) and Giza21 (P6) were sown in sterilized Patmos soil as 10 seeds per each pot of one liter capacity and $25 \mathrm{~cm}$ diameter, and grown under $25{ }^{\circ} \mathrm{C}$ temperature. The pots under both control and drought conditions were irrigated 
with $50 \mathrm{ml}$ of water (its water holding capacity) and poly ethylene glycol (PEG) solution respectively twice per week. The drought incidence was satisfied during the experimental agricultural work by adjusting to different concentrations with PEG. Drought stress induced by polyethylene glycol 6000 (PEG 6000) with concentrations of; zero, $5 \%, 10 \%$ and $15 \%(w / v)$ to represent control, -0.05 , 0.15 and $-0.3 \mathrm{MPa}$ (water potential) respectively. The following morphological and Physiological parameters were recorded after treated genotypes with the different concentrations of PEG.

\section{A-1- Morphological characters}

- Seedling, root and shoot length:

The length of either shoot or root of $\mathbf{3 0}$ days old seedlings was measured and expressed in $\mathrm{cm}$. Samples were represented by all varieties grown under control, 5\%, 10\% and 15\% PEG treatment conditions. Rate of loss of either plant length at $15 \%$ PEG concentration compared to control was calculated according to the following equation:

$$
\begin{aligned}
& \text { Rateof loss } \%=
\end{aligned}
$$

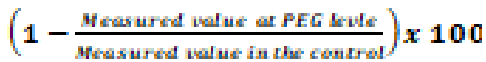

\section{A-2- Physiological characters}

\section{- Estimation of chlorophyll content:}

The samples were taken from soybean fresh leaves to estimate chlorophyll content according to Lichtenthaler and Wellburn, (1983) using the following formulae:

Chlorophyll a = 12.21 OD663 - 2.81 OD646;

Chlorophyll $b=20.13$ OD646 - 5.03 OD663;

Where: $O D$ is the optical density

\section{Estimation of proline content}

Free proline content was measured according to the method of Bates et al.,
(1973). The free proline content was expressed as $\mu \mathrm{g} / \mathrm{g}$. DW according to the following equation:

Proline content $(\mu \mathrm{g} / \mathrm{g} . \mathrm{DW})=$. $\frac{36.23 \times \text { O.D } X \text { total volume }}{2 \times \text { dry weight of sample }}$

\section{B- Field experiment:}

A diallel cross set involving the six parents was made in 2017, to produce the F1-generation. The six parents were; Lakota (P1), Giza82 (P2), D89-8940 (P3), Dr101 (P4), Line162 (P5) and Giza21 (P6). In 2018 all the mating progenies (six parents and 15 F1 seeds) were divided into two divisions and evaluated in two adjacent experiments; every experiment designed in a complete randomized block design (RCBD) with three replications. In the first experiment all genotypes were evaluated under the normal irrigation conditions with a full irrigation meanwhile in the second one the same genotypes were evaluated under drought stress with $50 \%$ irrigation. The design of irrigation was shown in Table 1 and the experimental soil physical and chemical properties are presented in Table 2. The plot size was one ridge. Each ridge was three meters long and $70 \mathrm{~cm}$ apart. Seeds were sowing on one side of the ridge at $20 \mathrm{~cm}$ between hills with one seed per hill. The wet sowing method called (Herati) was carried out on $20^{\text {th }}$ May, 2018 and all the other cultural practices were followed as recommended. The studied characters were; days to maturity, plant height $(\mathrm{cm})$, main root length $(\mathrm{cm})$, number of pods/plant and seed yield Iplant (g).

General and specific combining ability estimates were obtained by employing Griffing's (1956) diallel cross analysis designated as a model-1 method-2. 
Table (1): Irrigation design under normal and stress experiments.

\begin{tabular}{|c|c|c|c|c|c|c|}
\hline Irrigation date & $20 / 6 / 2018$ & $5 / 7 / 2018$ & $20 / 7 / 2018$ & $5 / 8 / 2018$ & $20 / 8 / 2018$ & $5 / 9 / 2018$ \\
\hline $\begin{array}{c}\text { Normal } \\
\text { irrigation }\end{array}$ & Irrigated & Irrigated & Irrigated & Irrigated & Irrigated & Irrigated \\
\hline Stress irrigation & Irrigated & $\begin{array}{c}\text { Non } \\
\text { irrigated }\end{array}$ & Irrigated & $\begin{array}{c}\text { Non } \\
\text { irrigated }\end{array}$ & Irrigated & $\begin{array}{c}\text { Non } \\
\text { Irrigated }\end{array}$ \\
\hline
\end{tabular}

Table (2): Physiochemical properties of experimental soil in both seasons.

\begin{tabular}{|c|c|c|}
\hline \multirow{2}{*}{ Properties } & \multicolumn{2}{|c|}{ Seasons } \\
\hline & 2017 & 2018 \\
\hline \multicolumn{3}{|c|}{ Particle size distribution } \\
\hline Clay \% & 60.41 & 59.61 \\
\hline Slit \% & 32.5 & 31.8 \\
\hline Sand \% & 7.09 & 8.59 \\
\hline Texture & Clay & Clay \\
\hline $\mathrm{CaCO}_{3} \%$ & 3.15 & 2.45 \\
\hline $\mathrm{PH}$ & 7.70 & 7.75 \\
\hline E.C dS/m & 1.93 & 1.88 \\
\hline \multicolumn{3}{|c|}{ Soluble cations (meq/L) } \\
\hline $\mathrm{Ca}++$ & 6.12 & 5.10 \\
\hline $\mathrm{Mg}++$ & 3.54 & 2.61 \\
\hline $\mathrm{K}+$ & 1.56 & 1.64 \\
\hline $\mathrm{Na}+$ & 8.17 & 6.89 \\
\hline SAR & 3.73 & 3.53 \\
\hline \multicolumn{3}{|c|}{ Soluble Anions (meq/L) } \\
\hline Cl- & 10.11 & 8.42 \\
\hline $\mathrm{HCO}_{3}^{--}$ & 0.85 & 0.70 \\
\hline $\mathrm{SO}_{4}^{--}$ & 8.43 & 7.02 \\
\hline \multicolumn{3}{|c|}{ Available nutrient $\mathrm{mg} / \mathrm{kg}$} \\
\hline $\mathrm{K}+$ & 74.11 & 68.34 \\
\hline $\mathbf{P}$ & 2.66 & 2.34 \\
\hline $\mathbf{N}$ & 41.78 & 40.09 \\
\hline OM\% & 0.68 & 0.54 \\
\hline
\end{tabular}

\section{RESULTS AND DISCUSSION}

\section{A- Pre-breeding screening of parental genotypes:-}

A-1- Morphological characters:

A-1-1- Seedling length and water content:

Plant length and water content were inversely related to the increase of drought stress treatment, accordingly the highest decrease in length and water content was obtained with $15 \%$ PEG concentration in all genotypes (Figs 1 and 2). The results in Fig. 1 indicate that Genotypes response to $15 \%$ PEG treatment were differed significantly according to the decrease of total seedling length compared with control where the decrease percentage in seedling length were $62.74 \%$ in Lakota, $49.28 \%$ in Giza82, $34.91 \%$ in Giza21, 21.43\% in Line162, 19.97\% in D89-8940, and $17.25 \%$ in DR101. Seedling length (root and shoot) of each soybean 
genotypes are presented in Fig. 3. The results showed significantly decreased of root and shoot length in Lakota, Giza82 and Giza21 by increasing drought stress from zero (control) to 15\% PEG. except Lakota which showed non-significant decrease between $5 \%$ and $10 \%$ PEG concentrations in both shoot and root lengths. The non-significant decrease in seedling length (root and shoot) by increasing drought stress from 5 to $15 \%$ PEG compared with control in the three genotypes DR101, D89-8940 and Line162 and this seemed to be evidence about them tolerant to drought stress. In soybean, the stem length was decreased under water deficit conditions (Specht et al., (2001)). Stem length was significantly affected under water stress in soybean (Zhang et al., (2004)). Drought stress reduced the number of nodes which is a result due to the reduction of main stem height and the decreased node emergence rate (Desclaux et al., (2000)). Liu et al., (2005) found that there is a positive correlation between drought tolerance and dry root weight/plant weight; total root length/ plant weight, and root volume/plant weight.

The obtained data in Fig. 2 showed that sharply loss in total water contents of Lakota seedling (77.36\%) followed by Giza82 $(72.11 \%)$ while, the lowest loss in total water content were observed in DR101 seedling (14.59\%) followed by D89-8940 (16.72\%) and then Line162 (19.07). Loss of Water content for each parental genotypes (Fig. 3) showed that water content in seedlings of Lakota, Giza82 and Giza21 sharply decreased when the drought stress increase from $5 \%$ PEG to $15 \%$ PEG. Increasing of drought stress from $5 \%$ to $10 \%$ as well as $15 \%$ PEG concentrations, due to insignificant water content decreasing in DR101, D89-8940 and Line162.

The decline of root and shoot as a result drought condition may due to cell decline as a method to reduce water loss during transpiration. The results were in agreement with those obtained by Abass and Mohamed, (2011) who reported that the plant growth parameters of common bean (shoot and root length, fresh and dry weights of shoots and roots) decreased significantly with increasing drought stress as compared with control plants. The ability of any genotypes to keep water content under drought conditions my an indicator about their tolerance to this stress (Kumar and Sharma, (2010)).

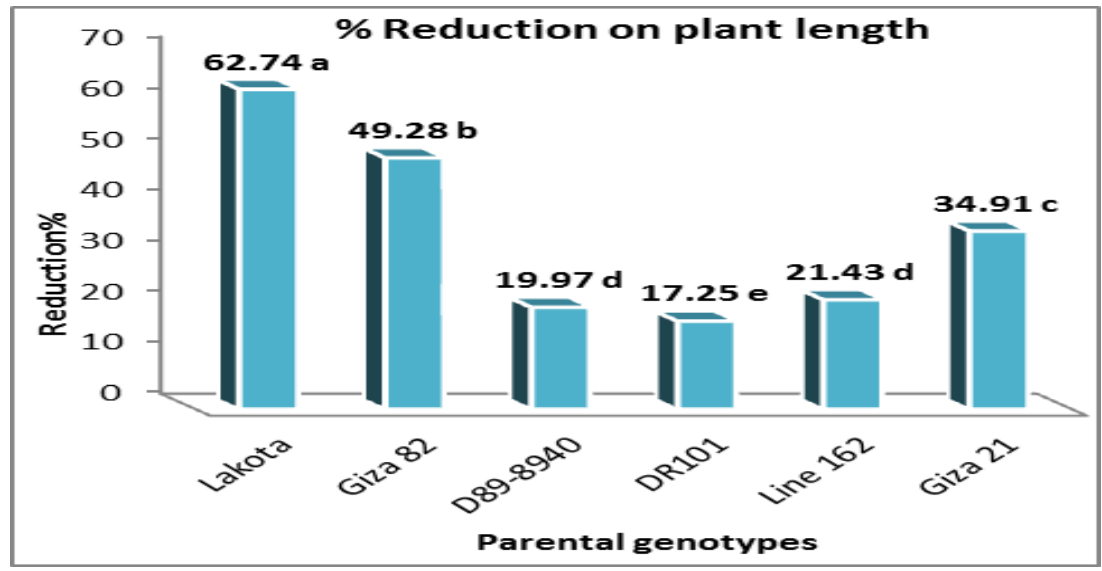

Fig. 1: Reduction percentage in seedling length of screened soybean parents under different PEG concentrations (5\%, 10\%, and $15 \%)$. 


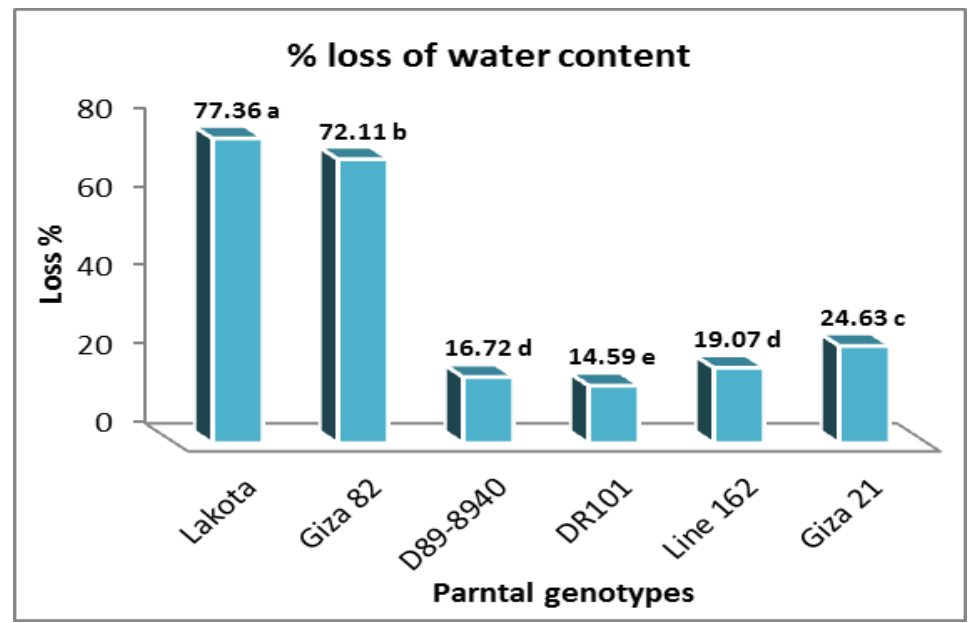

Fig. 2: percentage of loss in water content of screened soybean parents under different PEG concentrations $(5 \%, 10 \%$, and $15 \%)$.
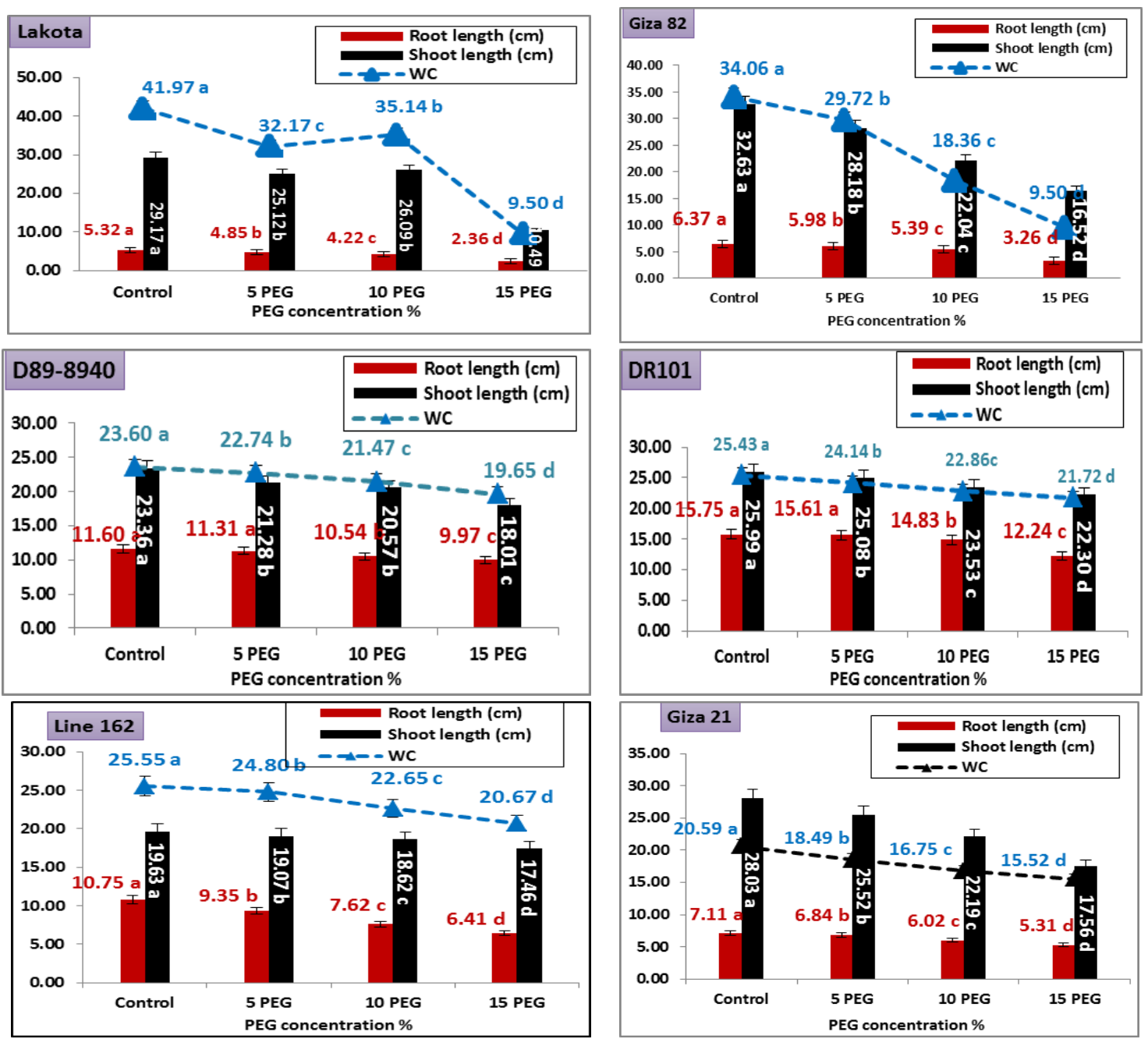

Fig. 3: Effect of different PEG concentrations (5\%, $10 \%$ and $15 \%)$ in shoot, root lengths of screened soybean genotypes seedling. 


\section{A-2- Physiological Measurements:}

\section{A-2-1- Pigments content.}

The popular photosynthetic pigments (Ch.a and Ch.b) presented in Fig. 4 indicated that the pigments content (Ch-a and ch-b) of DR101, Line162 and D898940 did not decrease significantly by increasing drought stress compared with control. On the other side, the pigments content sharply decreased in Lakota and Giza82 by increasing drought stress from $5 \%$ to $15 \%$ PEG compared with control. The negative effects of drought condition on some photosynthetic pigments (Ch. a and b) in this study consider indicator for sensitivity of genotypes toward this stress. In the same way Heba and
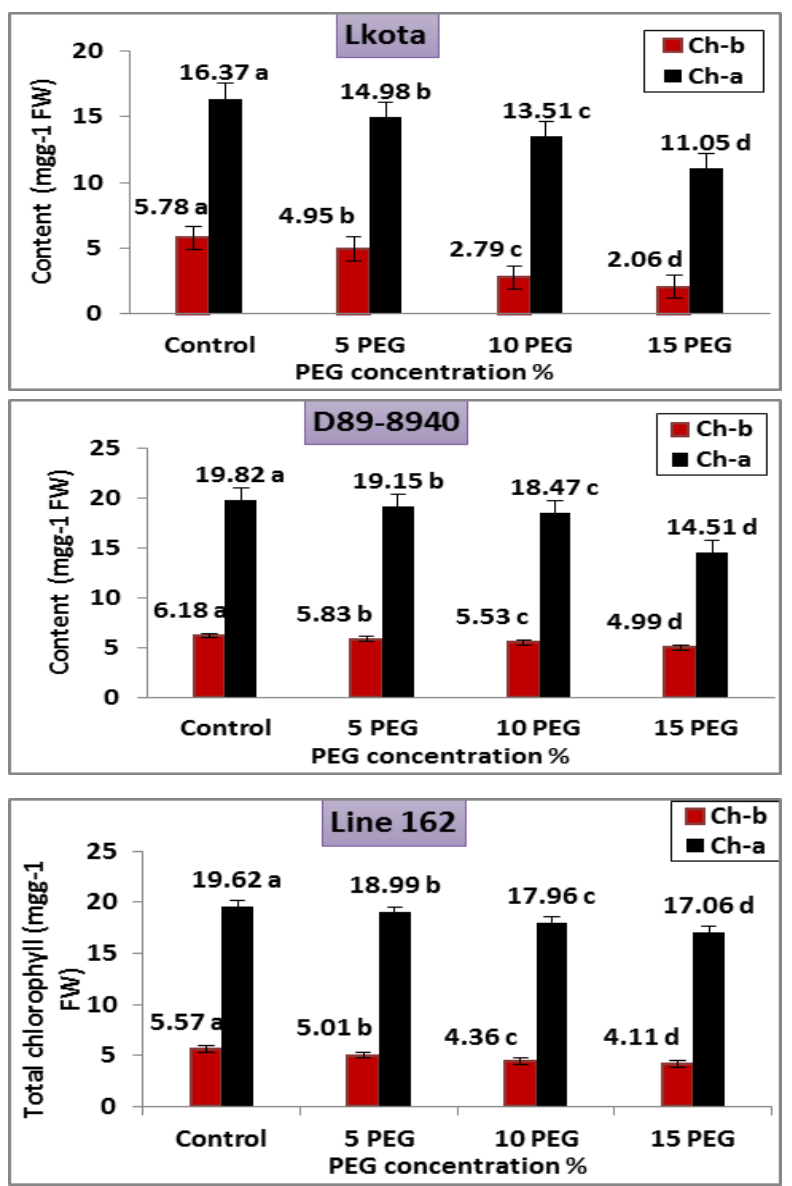

Fig. 4: Effect of different PEG concentrations (5\%, 10\%, and 15\%). in chlorophyll a and b content of screened soybean genotypes.

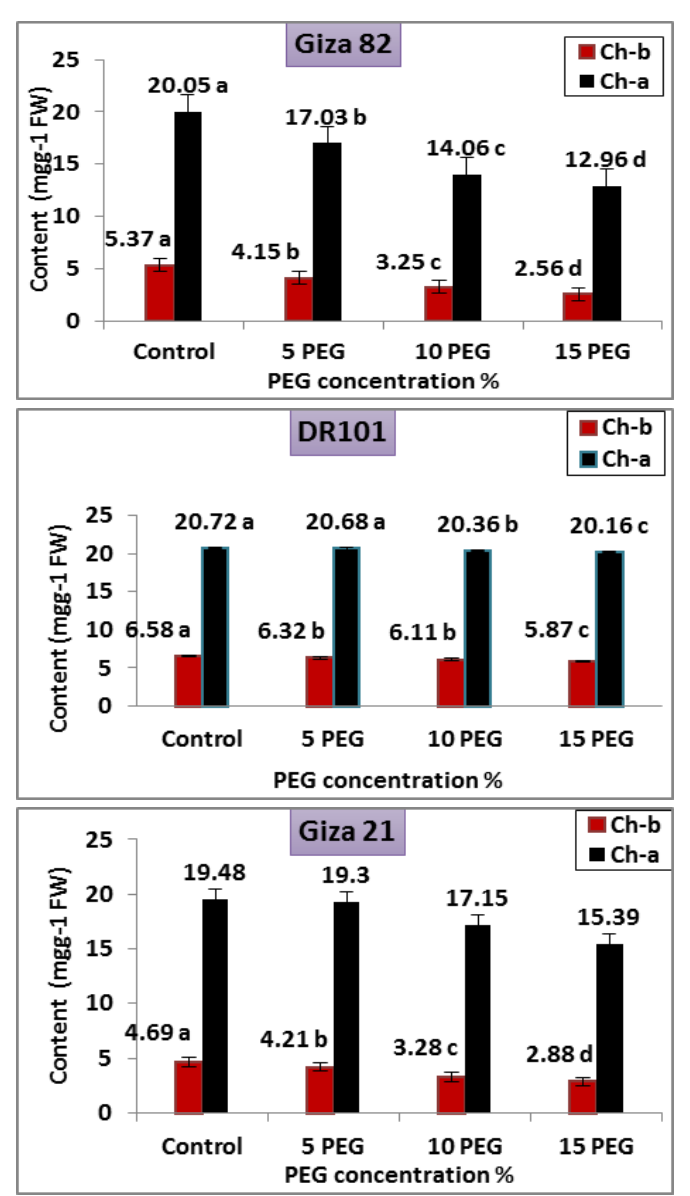

Shamia, (2014) found reduction in chlorophylls and carotenoids content under drought stress either under expermintal. Also, Zhang et al., (2007) found that drought stress decrease photosynthetic pigments (chl. a, chl. b, chl. $a+b$ and carotenoids) of soybean plants. Moreover, Abass and Mohamed (2011) reported that the decrease in the photosynthetic activity under drought stress as a result of highly significantly decreased of photosynthetic pigments with increasing the level of drought stress. The degree of chlorophyll reduction in soybean leaves was correlated with the strength of drought treatments (Masoumi et al., (2012)). 


\section{A-2-2- Proline content}

Data in Fig. 5 showed that the highly significant differences were detected among all screened genotypes in their content of Proline under all drought levels $(5 \%, 10 \%$ and $15 \%$ PEG). The increasing drought stress associated with sharply increase in proline content of DR101, D89-8940 and Line162 and associated with moderate increase in Giza21. While, the increase of drought levels led to low increase in proline in the two genotypes Lakota and Giza82. All genotypes reached the content of proline under the drought level 15\% PEG. The increasing of Proline accumulation during drought stress in various plant species have been reported by many researcher such as on soybean, (Nazarli et al., (2011)). Our finding was in the same line with Kim et al., (2004) who reported that water stress induced an increase in the levels of free amino acids specially, Proline. These protein regarded as a part of defense system against stress and this corresponds to Abdelgawad et al., (2015). Comparing a drought tolerant and a drought sensitive soybean did not reveal an increase in proline level under stress, although the proline level of the tolerant cultivar was higher than that in the sensitive cultivar (Silvente et al., (2012)).

\section{B- Field study:}

\section{B-1- Analysis of variance}

The analysis of variance for all studied traits at each irrigation treatments and combined analysis are presented in Table (3). Results indicated that mean square due to irrigation treatments were significant for all traits except 100 -seed weight and seed yield/ plant, indicating that overall differences between the two irrigation treatments.

Mean square for genotypes, parents, crosses and parent vs. crosses were significant for all studied traits under both irrigation treatments and the combined analysis except parents vs. crosses for maturity date under normal irrigation, indicating a wide genetic diversity among the parental materials that used in this present investigation. Iqbal et al., (2003) study the genetic control of some important agronomic and quality characters and they found highly significant differences among parents and their hybrids in $F_{1}$ generation were revealed by analysis of variance, for all the characters except for days to maturity. Mean square of interaction due to genotypes $x$ irrigation, parent $x$ irrigation and F1 $x$ irrigation were significant for all studied traits except for parent $x$ irrigation of main root length and seed yield/plant as well as genotypes $x$ irrigation and F1 $x$ irrigation of seed yield /plant. This result indicates that the parental materials and their crosses will ranked a varied response in the different irrigation conditions.

Agrawal et al., (2005) found that yield attributing characters in soybean might be governed by additive gene effects, whereas the non-additive and complex of additive and non-additive gene effects played an important role in the expression of yield attributing characters. Similarly, Shiv, et al., (2011) revealed that soybean parents and crosses differ significantly for general combining ability and specific combining ability effects. 


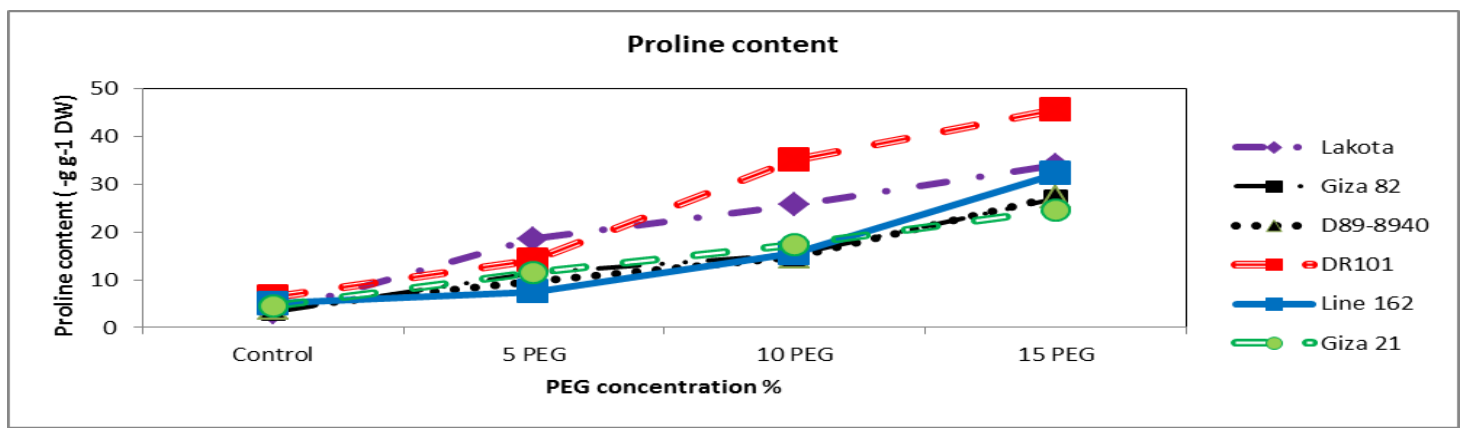

Fig.5: Effect of different PEG concentrations (5\%, 10\%, and 15\%). in proline content of screened soybean genotypes.

Table (3): Ordinary analysis of variance for all studied traits at each irrigation treatment and combined data.

\begin{tabular}{|c|c|c|c|c|c|c|c|c|c|c|c|}
\hline \multirow{2}{*}{ S.O.V. } & \multirow{2}{*}{$\mathbf{S}$} & \multirow{2}{*}{ C } & \multicolumn{3}{|c|}{ Days to maturity } & \multicolumn{3}{|c|}{ plant height $(\mathrm{cm})$} & \multicolumn{3}{|c|}{ Main root length $(\mathrm{cm})$} \\
\hline & & & Normal & Stress & Comb. & Normal & Stress & Comb. & Normal & Stress & Comb. \\
\hline Irri. & & 1 & & & $651.36^{* *}$ & & & $2675.37^{\star *}$ & & & $439.07^{\star *}$ \\
\hline Rep x Irri. & 2 & 4 & 0.19 & 0.42 & 0.28 & 2.62 & 6.35 & 3.89 & 0.48 & 1.17 & 1.59 \\
\hline Genotypes (G) & 20 & 20 & $627.08^{* *}$ & $632.93^{* *}$ & $1237.27^{* *}$ & $1630.10^{* *}$ & $1865.8^{* *}$ & $3201.76^{* *}$ & $46.92^{* *}$ & $115.33^{* *}$ & $149.66^{* *}$ \\
\hline Parents (P) & 5 & 5 & $662.42^{\star *}$ & $683.18^{\star *}$ & $1352.71^{* \star}$ & $755.16^{\star *}$ & $832.71^{\star \star}$ & $1385.33^{* *}$ & $24.61^{* *}$ & $70.12^{\star \star}$ & $67.88^{\star *}$ \\
\hline Crosses (F1) & 14 & 14 & $659.02^{* *}$ & 654.89 ** & $1279.64^{\star \star}$ & $1651.94^{* *}$ & $2169.76^{* *}$ & $3491.33^{* *}$ & $49.89^{* *}$ & 133.39 ** & $175.41^{* *}$ \\
\hline P vs F1 & 1 & 1 & 3.25 & $74.19^{\star \star *}$ & $66.98^{\star *}$ & $5699.12^{\star \star}$ & $2775.72^{\star *}$ & $8229.91^{* *}$ & $116.92^{\text {** }}$ & $88.45^{\star *}$ & $198.12^{\text {** }}$ \\
\hline G x Irri. & & 20 & & & $18.42^{* *}$ & & & $275.94^{\star \star}$ & & & $9.47^{* \star}$ \\
\hline$P \times$ Irri. & & 5 & & & $6.48^{\star *}$ & & & $165.22^{\text {** }}$ & & & 3.62 \\
\hline F1x Irri. & & 14 & & & $19.91^{* *}$ & & & $316.84^{* *}$ & & & $13.21^{* *}$ \\
\hline p vsF1 x Irri. & & 1 & & & $22.13^{\star *}$ & & & $256.95^{\star *}$ & & & 1.28 \\
\hline Error & 40 & 80 & 1.87 & 2.18 & 1.97 & 8.19 & 5.44 & 5.53 & 1.16 & 1.41 & 1.32 \\
\hline
\end{tabular}

Table 3: Cont.

\begin{tabular}{|c|c|c|c|c|c|c|c|c|c|c|c|}
\hline \multirow{2}{*}{ S.O.V. } & \multirow{2}{*}{$\mathbf{s}$} & \multirow{2}{*}{ C } & \multicolumn{3}{|c|}{ No. of pods/plant } & \multicolumn{3}{|c|}{ 100-seed weight(g) } & \multicolumn{3}{|c|}{ Seed yield/ plant (g) } \\
\hline & & & Normal & Stress & Comb. & Normal & Stress & Comb. & Normal & Stress & Comb. \\
\hline Irri. & & 1 & & & $8283.06^{* *}$ & & & 0.62 & & & 5835.27 \\
\hline Rep x Irri. & 2 & 4 & 0.59 & 0.78 & 0.69 & 0.62 & 0.03 & 0.32 & 1.85 & 2.17 & 1.94 \\
\hline Genotypes(G) & 20 & 20 & $3294.36^{* *}$ & $4468.42^{\star *}$ & $6997.38^{\star *}$ & $4.75^{\star \star}$ & $4.93^{* *}$ & $8.51^{\star *}$ & $2217.37^{* *}$ & $2279.11^{\star \star}$ & $4305.59 * *$ \\
\hline Parents (P) & 5 & 5 & $2290.91^{* *}$ & $3795.93^{* *}$ & 4045.11** & $6.96^{\star *}$ & $10.28^{* *}$ & $15.04^{\star *}$ & $1944.19^{* *}$ & $1497.32^{* *}$ & 3398.19** \\
\hline Crosses (F1) & 14 & 14 & $2749.43^{\star *}$ & $2854.65^{\star \star}$ & $5325.17^{* *}$ & $4.23^{* *}$ & $3.27^{* \star}$ & $6.63^{* \star}$ & $1250.55^{\star \star}$ & $1649.61^{\text {** }}$ & $2642.73^{* *}$ \\
\hline P vs F1 & 1 & 1 & $15940.6^{\text {** }}$ & $30423.61^{* *}$ & $45169.58^{* *}$ & $0.91^{*}$ & $1.47^{* *}$ & $2.35^{\star *}$ & $17118.83^{* *}$ & $15001.06^{* \star}$ & $32086.80^{* \star}$ \\
\hline G x Irri. & & 20 & & & $764.32^{\star \star *}$ & & & $1.17^{* *}$ & & & 193.82 \\
\hline$P \times$ Irri. & & 5 & & & $2018.09 * *$ & & & $2.21^{* *}$ & & & 40.66 \\
\hline F1x Irri. & & 14 & & & $268.99 * *$ & & & $0.88^{* *}$ & & & 258.13 \\
\hline p vsF1 x Irri. & & 1 & & & $1156.27^{* *}$ & & & 0.03 & & & 31.28 \\
\hline Error & 40 & 80 & 5.46 & 9.23 & 10.13 & 0.22 & 0.13 & 0.18 & 6.83 & 9.32 & 10.16 \\
\hline
\end{tabular}

* and ** significant at 0.05 and 0.01 levels of probability, respectively $\mathrm{S}=$ Degree of freedom for the single treatment. $\quad \mathrm{C}=$ Degree of freedom for combined data.

\section{B-2- Mean performance:}

Mean performance for all studied traits at each irrigation treatments and combined analysis are presented in Table (4). The results clearly indicate that the parental genotypes Giza 82 and Giza21 showed the best mean values for maturity date under both irrigation treatments and the combined analysis. Meanwhile the two crosses Lakota $x$ Giza21 and Giza82 x Giza21 expressed the best mean values under both irrigation treatments and the combined analysis in the same trait.

Time of flowering is a major trait of a crop adaptation to the environment, 
particularly when the growing season is restricted by terminal drought and high temperatures. Developing short-duration varieties has been an effective strategy for minimizing yield loss from terminal drought, as early maturity helps the crop to avoid the period of stress (Kumar and Abo, (2001)).

With respect to plant height the parent D89-8940 followed by Giza 21 and Dr101 had the highest mean values in both irrigation treatments and the combined analysis, meanwhile the drought condition did not effect seriously on the plant height of the parental combinations of D89-8940 and Dr101 with Lakota, Giza82 and Giza21 where they expressed the highest mean values for this trait in both irrigation treatments and the combined analysis. The main root length sharply increase in the two parental genotypes D89-8940 and Dr101 from 19.53 and 24.23 in the normal irrigation to 25.30 and 30.57 in stress condition. the same parents registered the longest roots under both irrigation treatments and the combined analysis. On the other side, the two cross combinations Lkota $x$ Dr101, Giza82 x Dr101 D89-8940 x Dr101 and Dr101 $x$ Line162 give the highest mean values under both irrigation treatments and the combined analysis for main root length. For number of pods/plant the two parental genotypes D89-8940 and Line162 registered the highest mean values under both irrigation treatments and the combined analysis. On the other side, the two cross combinations D89-8940 $x$ Line162 and D89-8940 X Giza21 give the highest number of pods /plant under both irrigation treatments and the combined analysis for number of pods I plant. Water stress reduces seed yield in soybean usually as a result of fewer pods and seeds per unit area (Specht et al., (2001)).

Table (4): Mean performance for all studied traits of six parental genotypes and their F1 crosses at each irrigation treatments and combined data.

\begin{tabular}{|c|c|c|c|c|c|c|c|c|c|}
\hline \multirow{2}{*}{ Genotypes } & \multicolumn{3}{|c|}{ Days to Maturity } & \multicolumn{3}{|c|}{ plant height $(\mathrm{cm})$} & \multicolumn{3}{|c|}{ main root length $(\mathrm{cm})$} \\
\hline & Normal & Stress & Comb. & Normal & Stress & Comb. & Normal & Stress & Comb. \\
\hline Lkota & 113.93 & 107.60 & 110.77 & 75.33 & 68.07 & 71.70 & 18.50 & 21.10 & 19.80 \\
\hline Giza82 & 108.93 & 105.60 & 107.27 & 78.73 & 68.60 & 73.67 & 15.90 & 18.90 & 17.40 \\
\hline D89-8940 & 123.93 & 116.27 & 120.10 & 112.13 & 100.27 & 106.20 & 19.53 & 25.30 & 22.42 \\
\hline Dr101 & 145.60 & 142.27 & 143.94 & 83.60 & 100.00 & 91.80 & 24.23 & 30.57 & 27.40 \\
\hline Line162 & 136.27 & 128.27 & 132.27 & 73.60 & 66.40 & 70.00 & 18.97 & 22.67 & 20.82 \\
\hline Giza21 & 110.93 & 104.60 & 107.77 & 100.40 & 92.27 & 96.34 & 18.80 & 21.53 & 20.17 \\
\hline Lkota x Giza82 & 107.60 & 95.70 & 101.65 & 96.73 & 58.33 & 77.53 & 17.60 & 19.63 & 18.62 \\
\hline Lkota x D89-8940 & 129.60 & 125.70 & 127.65 & 129.93 & 125.60 & 127.77 & 23.97 & 27.63 & 25.80 \\
\hline Lkota x Dr101 & 129.27 & 125.37 & 127.32 & 125.93 & 124.93 & 125.43 & 28.17 & 33.17 & 30.67 \\
\hline Lkota x Line162 & 121.27 & 118.93 & 120.10 & 79.60 & 59.73 & 69.67 & 19.40 & 20.60 & 20.00 \\
\hline Lkota x Giza21 & 98.60 & 95.11 & 96.86 & 133.83 & 84.53 & 109.18 & 18.83 & 20.00 & 19.42 \\
\hline Giza82 x D89-8940 & 121.27 & 116.27 & 118.77 & 128.87 & 125.53 & 127.20 & 21.50 & 28.83 & 25.17 \\
\hline Giza82 x Dr101 & 145.60 & 142.67 & 144.14 & 127.33 & 123.67 & 125.50 & 26.87 & 33.53 & 30.20 \\
\hline Giza82 x Line162 & 125.93 & 117.93 & 121.93 & 75.40 & 69.87 & 72.64 & 19.40 & 20.67 & 20.04 \\
\hline Giza82 x Giza21 & 96.27 & 98.37 & 97.32 & 93.27 & 91.20 & 92.24 & 19.10 & 19.37 & 19.24 \\
\hline D89-8940 x Dr101 & 136.27 & 134.97 & 135.62 & 125.73 & 125.07 & 125.40 & 32.63 & 39.97 & 36.30 \\
\hline D89-8940 x Line162 & 130.27 & 128.27 & 129.27 & 78.60 & 68.33 & 73.47 & 20.20 & 20.20 & 20.20 \\
\hline D89-8940 x Giza21 & 116.60 & 114.93 & 115.77 & 127.60 & 111.93 & 119.77 & 19.23 & 21.10 & 20.17 \\
\hline Dr101 x Line162 & 142.27 & 136.23 & 139.25 & 90.27 & 85.60 & 87.94 & 25.33 & 30.00 & 27.67 \\
\hline Dr101 x Giza21 & 116.27 & 116.27 & 116.27 & 131.60 & 126.60 & 129.10 & 22.83 & 31.83 & 27.33 \\
\hline Line162 x Giza21 & 139.13 & 128.60 & 133.87 & 80.57 & 79.00 & 79.79 & 20.00 & 22.30 & 21.15 \\
\hline L.S.D. $5 \%$ & 1.88 & 2.03 & 1.91 & 3.93 & 3.21 & 3.19 & 1.48 & 1.63 & 1.56 \\
\hline L.S.D. $1 \%$ & 2.71 & 2.92 & 2.72 & 5.66 & 4.61 & 4.56 & 2.13 & 2.35 & 2.23 \\
\hline
\end{tabular}


Genetic behavior of some soybean genotypes under normal and stress ......

Table (4): Cont.

\begin{tabular}{|l|c|c|c|c|c|c|c|c|c|}
\hline \multirow{2}{*}{ Genotypes } & \multicolumn{3}{|c|}{ No. of pods/plant } & \multicolumn{3}{c|}{100 seed weight(g) } & \multicolumn{3}{c|}{ Seed yield/plant (g) } \\
\cline { 2 - 9 } & Normal & Stress & Comb. & Normal & Stress & Comb. & Normal & Stress & Comb. \\
\hline Lkota & 48.27 & 38.63 & 43.45 & 15.00 & 13.41 & 14.20 & 26.88 & 16.55 & 21.72 \\
\hline Giza82 & 59.64 & 47.27 & 53.46 & 13.57 & 14.67 & 14.12 & 39.48 & 29.12 & 34.30 \\
\hline D89-8940 & 108.75 & 97.66 & 103.21 & 16.10 & 17.67 & 16.89 & 80.88 & 67.69 & 74.29 \\
\hline Dr101 & 78.78 & 75.67 & 77.23 & 14.55 & 14.10 & 14.33 & 52.11 & 48.97 & 50.54 \\
\hline Line162 & 112.43 & 93.96 & 103.20 & 16.68 & 17.33 & 17.01 & 89.29 & 72.36 & 80.83 \\
\hline Giza21 & 106.53 & 83.01 & 94.77 & 17.74 & 17.00 & 17.37 & 79.79 & 61.85 & 70.82 \\
\hline Lkota x Giza82 & 91.46 & 72.90 & 82.18 & 16.40 & 16.64 & 16.52 & 67.00 & 41.20 & 54.10 \\
\hline Lkota x D89-8940 & 119.24 & 114.79 & 117.02 & 14.28 & 14.90 & 14.59 & 85.67 & 83.67 & 84.67 \\
\hline Lkota x Dr101 & 112.33 & 109.67 & 111.00 & 15.53 & 15.34 & 15.43 & 95.67 & 90.67 & 93.17 \\
\hline Lkota x Line162 & 104.05 & 94.55 & 99.30 & 14.80 & 15.36 & 15.08 & 93.25 & 67.89 & 80.57 \\
\hline Lkota x Giza21 & 87.00 & 71.71 & 79.36 & 17.70 & 17.54 & 17.62 & 83.67 & 61.05 & 72.36 \\
\hline Giza82 x D89-8940 & 70.38 & 65.35 & 67.87 & 15.40 & 15.32 & 15.36 & 80.55 & 75.88 & 78.22 \\
\hline Giza82 x Dr101 & 90.46 & 85.46 & 87.96 & 15.20 & 16.19 & 15.69 & 70.40 & 68.73 & 69.57 \\
\hline Giza82 x Line162 & 97.07 & 74.37 & 85.72 & 14.12 & 15.46 & 14.79 & 77.19 & 68.25 & 72.72 \\
\hline Giza82 x Giza21 & 144.93 & 104.06 & 124.50 & 14.81 & 15.16 & 14.99 & 100.79 & 63.60 & 82.20 \\
\hline D89-8940 x Dr101 & 145.81 & 147.48 & 146.65 & 16.07 & 15.93 & 16.00 & 103.70 & 102.70 & 103.20 \\
\hline D89-8940 x Line162 & 156.27 & 152.27 & 154.27 & 16.36 & 15.64 & 16.00 & 124.01 & 115.68 & 119.85 \\
\hline D89-8940 x Giza21 & 159.49 & 150.12 & 154.81 & 16.88 & 15.02 & 15.95 & 119.47 & 91.80 & 105.64 \\
\hline Dr101 x Line162 & 124.89 & 122.89 & 123.89 & 17.36 & 17.98 & 17.67 & 126.74 & 120.74 & 123.74 \\
\hline Dr101 x Giza21 & 152.33 & 145.99 & 149.16 & 15.40 & 16.07 & 15.73 & 119.72 & 116.72 & 118.22 \\
\hline Line162 x Giza21 & 158.34 & 116.98 & 137.66 & 17.80 & 17.97 & 17.89 & 121.49 & 86.84 & 104.17 \\
\hline L.S.D. 5 \% & 3.21 & 4.18 & 4.32 & 0.78 & 0.62 & 0.69 & 3.59 & 4.20 & 4.33 \\
\hline L.S.D. 1 \% & 4.62 & 6.01 & 6.17 & 1.04 & 0.81 & 0.91 & 5.17 & 6.04 & 6.18 \\
\hline
\end{tabular}

With respect to 100 -seed weight the three parental genotypes Giza 21, D898940 and Line 162 had the highest 100seed weight among all tested parents. While, the three crosses Lkota $\times$ Giza21, Dr101 x Line162 and Line162 x Giza21 showed the highest 100 -seed weight among all tested crosses. For seed yield $I$ plant, both the parental genotypes D898940 and Line162 recorded the highest mean values in both irrigation treatments and the combined analysis, meanwhile, the two crosses D89-8940 x Line162 and Dr101 x Line162 expressed the best mean values in both irrigation treatments and the combined analysis in the same trait.

The effect of drought on the mean performance of number of pods /plant and seed yield /plant has been reported by many authors before such as Kobraei et al., (2011) and Aminifar et al., (2013).

\section{B-3- Heterosis relative to better parent.}

Mean square due to parent vs. crosses were highly significant for all studies traits in both irrigation treatments and their combined analysis except number of days to maturity in the normal irrigation and this may a clear evidence about the wide genetic diversity among the parental genotypes used in this study (Table 3). Also, mean square due to parent vs. crosses $x$ irrigation (Table 3) were highly significant for number of days to maturity, plant height and number of pods/plant while, the interaction of heterosis with irrigation were insignificant for main root length, 100-seed weight and seed yield/plant. The significant of the interaction between heterosis and irrigation indicated that the heterotic effect of the F1 crosses will be 
differing from an irrigation condition to another.

The results in Table 5 indicated that only the two crosses Lkota $x$ Giza21 and Giza82 x Giza21 showed a significant negative desirable heterotic effect relative to better parent number of days to maturity in both irrigation conditions and their combined data. While, the three crosses Lkota x Dr101, Giza82 x Dr101 and Dr101 x Giza21 had the highest significantly heterotic effects relative to better parent for plant height across the two irrigation environments among seven crosses showed the same positive significant heterotic effect relative to better parent in this trait in both normal, stress irrigation as well as the combined data. For main root length five crosses among the fifteen F1 crosses showed highly positive heterotic effect relative to better parent in both irrigation treatments and the combined data. The two crosses Lkota x D89-8940 and D89-8940 x Dr101 had the highest positive significant heterosis in both irrigation treatments and the combined data for main root length. For number of pods/plant twelve cross across the two irrigation treatments expressed significant positive heteritic effect relative to better parent. Among these twelve crosses the three crosses Lkota X Giza82, D89-8940 X Giza21 and Dr101 $x$ Giza21 had the highest desirnle heterotic effects relative to better parent for number of pods/plant in both irrigation treatments as well as the combined data. Respect to 100-seed weight only the two crosses Lkota $x$ Giza82 and Lkota $x$ Dr101 showed significantly positive desirable heterotic effects relative to better parent in both irrigation treatments as well as the combined data. For seed yield /plant twelve crosses expressed significant positive heterotic effects relative to better parent across the two irrigation treatments. The highest positive heterotic effects in this trait were obtained by Lkota x Giza82, Lkota x Dr101 and Dr101 $x$ Giza21 in both irrigation treatments as well as the combined data.

Table (5): Heterosis relative to better parent for all studied traits of the fifteen F1 crosses at each irrigation treatments and combined data.

\begin{tabular}{|c|c|c|c|c|c|c|c|c|c|}
\hline \multirow{2}{*}{ Genotypes } & \multicolumn{3}{|c|}{ Days to Maturity } & \multicolumn{3}{|c|}{ plant height (cm) } & \multicolumn{3}{|c|}{ main root length $(\mathrm{cm})$} \\
\hline & Normal & Stress & Comb. & Normal & Stress & Comb. & Normal & Stress & Comb. \\
\hline & & $-9.37^{* *}$ & $-5.24^{\star *}$ & $22.86^{* *}$ & $14.97^{* *}$ & $5.24^{*}$ & -4.86 & -6.97 & -5.96 \\
\hline Lkota $\times$ D & & $16.82^{* *}$ & $15.24^{* *}$ & $15.87^{\star *}$ & $25.26^{* *}$ & $20.31^{* *}$ & $22.73^{* *}$ & 9.21* & $15.08^{* *}$ \\
\hline Lkota x Dr101 & $13.46^{\star *}$ & $16.51 * *$ & $14.94^{* *}$ & $50.63^{* *}$ & $24.93^{* *}$ & $36.63^{* *}$ & 16.26 ** & $8.51^{* *}$ & $11.93^{* *}$ \\
\hline Lkota x Line162 & $44^{* *}$ & $10.53^{* *}$ & $8.42^{\star *}$ & $5.67^{*}$ & $-12.25^{\star *}$ & $-2.83^{* *}$ & 2.27 & $-9.13^{*}$ & -3.94 \\
\hline Lkota x Giza21 & $11.12^{* *}$ & $-9.07^{* *}$ & $-10.12^{* *}$ & 33.30 ** & $-8.39 * *$ & $13.33^{* *}$ & 0.16 & -7.11 & -3.72 \\
\hline Giza82 x D89-8940 & $11.33^{* *}$ & $10.10 * *$ & $10.72^{\text {** }}$ & $14.93^{* *}$ & $25.19 * *$ & $19.77^{* *}$ & $10.09 *$ & $13.95^{* *}$ & $12.27^{* *}$ \\
\hline Giza82 x Dr101 & $33.66^{\star *}$ & $35.10 * *$ & $34.37 * *$ & $52.31 * *$ & 23.67 ** & $36.71 * *$ & $10.90 * *$ & $9.68^{* *}$ & $10.22^{\star *}$ \\
\hline Giza82 x Line162 & $15.61^{* *}$ & $11.68 * *$ & $13.67^{* *}$ & -4.23 & 1.85 & -1.40 & 2.27 & $-8.82^{*}$ & -3.75 \\
\hline Giza82 x Giza21 & $-11.62^{* *}$ & $-5.96 * *$ & $-9.28^{* *}$ & $-7.10^{* *}$ & -1.16 & $-4.26^{*}$ & 1.60 & $-10.03^{*}$ & -4.61 \\
\hline D89-8940 x Dr101 & .90 & $16.08 * *$ & $12.92^{\star *}$ & & $24.73^{\star *}$ & & $34.67^{* *}$ & $30.75^{\star *}$ & $32.48^{\star *}$ \\
\hline D89-8940 x Line162 & $5.12^{\star *}$ & $10.32^{* *}$ & $7.64^{* *}$ & $-29.90 * *$ & $-31.85^{\star \star}$ & $-30.82^{\star *}$ & 3.43 & $-20.16^{* *}$ & $-9.90 *$ \\
\hline D89-8940 x Giza21 & $5.11^{* *}$ & $9.88^{* *}$ & $7.42^{* *}$ & $13.80^{* *}$ & $11.63^{\star *}$ & $12.78^{\star *}$ & -1.54 & $-16.60 * *$ & $-10.04^{\star *}$ \\
\hline Dr101 x Line162 & $4.40 * *$ & $6.21 * *$ & & $7.98^{* *}$ & -14.40 ** & $-4.20 *$ & 4.54 & -1.86 & 0.99 \\
\hline Dr101 x Giza21 & $4.81^{* *}$ & $11.16^{* *}$ & 7.89 ** & $31.08 * *$ & 26.60 ** & $34.00 * *$ & -5.78 & 4.12 & -0.26 \\
\hline Line162 x Giza21 & $25.42 * *$ & $22.94^{* *}$ & $24.22^{* *}$ & $-19.75^{\star *}$ & $-14.38^{\star *}$ & $-17.18^{* *}$ & 5.43 & -1.63 & 1.59 \\
\hline
\end{tabular}


Genetic behavior of some soybean genotypes under normal and stress ......

Table (5): Cont.

\begin{tabular}{|c|c|c|c|c|c|c|c|c|c|}
\hline \multirow{2}{*}{ Genotypes } & \multicolumn{3}{|c|}{ No. of pods/plant } & \multicolumn{3}{|c|}{100 seed weight(g) } & \multicolumn{3}{|c|}{ Seed yield/plant (g) } \\
\hline & Normal & Stress & Comb. & Normal & Stress & Comb. & Normal & Stress & Comb. \\
\hline & & 54.22 & $53.72^{* *}$ & & $13.43^{* *}$ & & $9.71 * *$ & $41.48 * *$ & $57.73 * *$ \\
\hline Lkota x D89-8940 & & $17.54^{\star *}$ & $13.38^{\star *}$ & $-11.30 * *$ & $-15.68^{* *}$ & $-13.62^{\star *}$ & $5.92^{*}$ & $23.61^{\star *}$ & $13.97^{\text {** }}$ \\
\hline Lkota x Dr101 & $2.59 * *$ & $44.93^{\star *}$ & $43.73 * *$ & $3.53^{* *}$ & 8.79 ** & $7.68 * *$ & $83.59 * *$ & $85.15^{\star \star}$ & $84.35^{\star \star}$ \\
\hline Lkota x L & & 0.63 & -3.78 & $-11.27^{* *}$ & $-11.37^{* *}$ & $-11.35^{\star *}$ & $4.43^{*}$ & $-6.18^{*}$ & -0.32 \\
\hline Lkota x Giza21 & & $13.61^{\text {** }}$ & $-16.26^{* *}$ & -0.23 & 3.18 & & $4.86^{*}$ & -1.29 & 2.17 \\
\hline Giza82 x D89-8940 & $-35.28 * \star$ & $-33.08^{\star *}$ & $-34.24^{\star *}$ & -4.35 & $-13.30 * *$ & $-9.06^{\star *}$ & 0.41 & $12.10^{* *}$ & 5.29 \\
\hline Giza82 x Dr101 & & $12.94^{\star *}$ & $13.89 * *$ & 4.47 & $10.36^{* *}$ & 9.49 ** & 35.10 ** & $40.35^{\star *}$ & $37.65^{\star *}$ \\
\hline Giza82 x Line162 & $-13.66^{* *}$ & $-20.85^{\star *}$ & $-16.94^{\star *}$ & $-15.35^{\star *}$ & $-10.79 * *$ & $-13.05^{\star *}$ & $-13.55^{\star *}$ & -5.68 & $-10.03^{* *}$ \\
\hline Giza82 x Giza21 & $36.05^{\star *}$ & $25.36 * *$ & $31.37^{* *}$ & $-16.52^{\star *}$ & $-10.82^{* *}$ & $-13.70^{* *}$ & $26.32 * *$ & 2.83 & $16.07^{\star *}$ \\
\hline D89-8940 x Dr101 & & & 42.09** & -0.19 & & $-5.27^{*}$ & $28.21 * *$ & $51.72^{* *}$ & $38.92^{\text {** }}$ \\
\hline D89-8940 x Line162 & $38.99 * *$ & $55.92^{* *}$ & $49.47^{\star *}$ & & $-11.49 * *$ & $-5.94^{\star *}$ & $38.88^{* *}$ & $59.87^{* *}$ & $48.27^{* *}$ \\
\hline D89-8940 x Giza21 & $46.66^{* *}$ & $53.72^{* *}$ & $50.00^{* *}$ & -4.85 & $-15.00 * *$ & $-8.18^{\star *}$ & $47.71^{\star *}$ & $35.62 * *$ & 42.20 ** \\
\hline Dr101 x Line162 & $11.08^{* *}$ & $30.79^{* *}$ & $20.05^{\star *}$ & 4.08 & $.75^{*}$ & $3.88^{*}$ & $41.94^{* *}$ & $66.86^{\star *}$ & $53.09 * *$ \\
\hline Dr101 x Giza21 & 42.99** & $75.87^{\star *}$ & $57.39 * *$ & $-13.19 * *$ & $-5.47^{\star *}$ & $-9.44^{\star *}$ & $50.04^{* *}$ & $88.71^{* *}$ & $66.93^{* *}$ \\
\hline Line162 x Giza21 & $40.83^{* *}$ & $24.50 * *$ & $33.39 * *$ & 0.34 & $3.69 *$ & 2.99 & 36.06 ** & $20.01^{* *}$ & $28.88^{* *}$ \\
\hline
\end{tabular}

\section{B-4- Combining ability analysis.}

Analysis of variance for combining ability as outlined by Griffing, (1956) method II model 1 in each irrigation treatment and the combined analysis for all studied traits is presented in Table (6). Our results indicated that mean square associated with general combining ability (GCA) and specific combining ability (SCA) were significant for all studied traits under normal, stress condition and combined analysis except SCA of main root length under normal irrigation. These results indicated that additive and non-additive types of gene action were important in the inheritance of the studied traits. The highly GCA/SCA ratio more than the unity was observed for all studied traits which may indicate that the largest part of the total genetic variability associated with these traits a result of additive and additive $x$ additive. The results agree with the results reported by
EL-Garhy et al., (2008), Perez et al., (2009) and Waly (2015).

\section{B-3-1- General combining ability effects:}

Estimates of GCA effects (ĝi) for individual parent for each trait under normal, stress and the combined data are presented in Table (7). The parental cultivar Giza21 exhibited the highly significant negative gi effect for days to maturity and highly positive ĝi effects for plant height, 100-seed weight under normal, stress and the combined analysis. The parental variety D89-8940 and Dr101 seemed to be excellent combiner for plant height, main root length and seed yield /plant under normal, stress and the combined analysis. Whereas, the parent Line162 and seemed to be excellent combiner for number of pods/plant, 100-seed weight and seed yield/plant under normal, stress and the combined analysis. 
Table (6): GCA and SCA analysis of variance for all studied traits at each irrigation treatments and combined analysis.

\begin{tabular}{|c|c|c|c|c|c|c|c|c|c|c|c|}
\hline \multirow{2}{*}{$\begin{array}{l}\text { Traits } \\
\text { S.O.V. }\end{array}$} & \multirow[b]{2}{*}{$\mathbf{S}$} & \multirow[b]{2}{*}{$\mathbf{C}$} & \multicolumn{3}{|c|}{ Maturity date (day) } & \multicolumn{3}{|c|}{ plant height $(\mathrm{cm})$} & \multicolumn{3}{|c|}{ Main root length $(\mathrm{cm})$} \\
\hline & & & Normal & Stress & Comb. & Normal & Stress & Comb. & Normal & Stress & Comb. \\
\hline GCA & 5 & 5 & $624.84^{* *}$ & $632.57^{\star *}$ & $1237.11^{* *}$ & $1590.48^{\star *}$ & $1840.63^{\star \star}$ & $3163.18^{\star *}$ & $55.09 * *$ & $140.85^{\star *}$ & $155.63^{* *}$ \\
\hline SCA & 15 & 15 & $70.97^{\star \star}$ & $69.73^{\star *}$ & $137.27^{* *}$ & $172.87^{\star *}$ & $210.89 * *$ & $360.93^{* *}$ & 2.56 & $3.47^{*}$ & $12.57^{* *}$ \\
\hline GCA x Irri. & & 5 & & & $5.11 * *$ & & & $140.67^{\star *}$ & & & $7.05^{\star *}$ \\
\hline SCA x Irri. & & 15 & & & $6.82^{* *}$ & & & $71.92^{\star *}$ & & & 1.83 \\
\hline Error & 40 & 80 & 0.62 & 0.72 & 0.65 & 2.71 & 1.78 & 1.84 & 0.38 & 0.46 & 0.44 \\
\hline GCA/SCA & & & 8.80 & 9.07 & 9.01 & 9.20 & 8.73 & 8.76 & 21.52 & 40.59 & 12.38 \\
\hline GCAx Irri./ GCA & & & & & 0.00 & & & 0.04 & & & 0.05 \\
\hline SCAx Irri./ SCA & & & & & 0.05 & & & 0.20 & & & 0.15 \\
\hline $\begin{array}{l}\text { GCAx Irri ISCAx } \\
\text { Irri. }\end{array}$ & & & & & 0.08 & & & 0.22 & & & 0.31 \\
\hline
\end{tabular}

Table (6): Cont.

\begin{tabular}{|c|c|c|c|c|c|c|c|c|c|c|c|}
\hline Traits & & & \multicolumn{3}{|c|}{ No. of pods /plant } & \multicolumn{3}{|c|}{100 seed weight(g) } & \multicolumn{3}{|c|}{ Seed yield/ plant (g) } \\
\hline S.o.v. & $\mathbf{s}$ & C & Normal & Stress & Comb. & Normal & Stress & Comb.b. & Normal & Stress & Comb. \\
\hline GCA & 5 & 5 & $3143.42^{* *}$ & $4450.96 * *$ & $6801.15^{\star \star}$ & $3.27^{\star \star}$ & $2.21^{\star \star}$ & $4.96^{* *}$ & $2221.33^{* \star}$ & $2173.52^{\star \star}$ & $4238.97^{\star *}$ \\
\hline SCA & 15 & 15 & $411.27^{* *}$ & $451.56^{* *}$ & $839.87^{* *}$ & $1.02^{* *}$ & $1.45^{\star *}$ & $2.13^{* *}$ & $217.46^{\star *}$ & 287.29 ** & $526.14^{\star *}$ \\
\hline GCA x Irri. & & 5 & & & $711.36^{* *}$ & & & $0.53^{* *}$ & & & $142.61^{* *}$ \\
\hline SCA $x$ Irri. & & 15 & & & $109.13^{\star *}$ & & & $0.34^{\star *}$ & & & $46.07^{* *}$ \\
\hline Error & 40 & 80 & 1.78 & 2.95 & 2.7 & 0.07 & 0.04 & 0.06 & 2.27 & 3.08 & 3.22 \\
\hline GCA/SCA & & & 7.64 & 9.86 & 8.10 & 3.20 & 1.52 & 2.32 & 10.21 & 7.57 & 8.06 \\
\hline $\begin{array}{c}\text { GCAx Irri.I } \\
\text { GCA }\end{array}$ & & & & & 0.10 & & & 0.11 & & & 0.03 \\
\hline $\begin{array}{c}\text { SCAx Irri.I } \\
\text { SCA }\end{array}$ & & & & & 0.13 & & & 0.16 & & & 0.09 \\
\hline $\begin{array}{l}\text { GCAx Irri } \\
\text { ISCAx Irri. }\end{array}$ & & & & & 0.80 & & & 1.53 & & & 0.38 \\
\hline
\end{tabular}

${ }^{*}$ and ${ }^{* *}$ significant at 0.05 and 0.01 levels of probability, respectively $S=$ Degree of freedom for the single treatment. $\quad \mathrm{C}=$ Degree of freedom for combined data.

Table (7): Estimates of gca effects (ĝi) for individual parent for each trait under normal, stress and combined data.

\begin{tabular}{|c|c|c|c|c|c|c|c|c|c|}
\hline Traits & Matu & rity date & (day) & plar & t height ( & $\mathrm{cm})$ & main $r$ & ot lengt & $(\mathrm{cm})$ \\
\hline Parent & Normal & Stress & Comb. & Normal & Stress & Comb. & Normal & Stress & Comb. \\
\hline Lkota & $-5.97^{\star *}$ & $-6.87^{* *}$ & $-5.84^{\star *}$ & 0.32 & $-8.94^{\star *}$ & $-4.18^{\star \star}$ & $-0.74^{* *}$ & $-1.48^{\star \star}$ & $-1.03^{* *}$ \\
\hline Giza82 & $-6.84^{* \star}$ & -7.60 ** & $-6.81^{* *}$ & $-8.79 * *$ & $-9.13^{\star *}$ & $-6.73^{* \star}$ & $-1.72^{\star \star}$ & $-2.36^{* *}$ & $-1.87^{* *}$ \\
\hline D89-8940 & $3.10 * *$ & $4.72^{\star *}$ & $3.13^{* *}$ & $10.33^{\star *}$ & $12.56 * *$ & $11.61^{* *}$ & $1.05^{* *}$ & $1.56^{* *}$ & $1.05^{\star *}$ \\
\hline Dr101 & 10.88 ** & $10.03^{* *}$ & 10.01 ** & $7.92^{* *}$ & $14.35^{\star *}$ & 10.30 ** & $3.98 * *$ & $6.59 * *$ & 5.37 ** \\
\hline Line162 & 8.31 ** & $7.66^{\star *}$ & $9.22 * *$ & $-16.46^{* *}$ & $-15.06^{* *}$ & $-18.28^{* *}$ & $-0.99 * *$ & $-2.14^{* *}$ & $-1.63^{* *}$ \\
\hline Giza21 & $-9.48^{* *}$ & $-7.94^{\star *}$ & $-9.71^{* *}$ & $6.68 * *$ & $6.22 * *$ & $7.28 * *$ & $-1.58^{\star *}$ & $-2.17^{* *}$ & $-1.89 * *$ \\
\hline LSD $g_{i} 5 \%$ & 0.51 & 0.55 & 0.26 & 1.04 & 0.75 & 0.44 & 0.31 & 0.24 & 0.14 \\
\hline LSD $g_{i} 1 \%$ & 0.68 & 0.72 & 0.34 & 1.38 & 1.00 & 0.57 & 0.40 & 0.31 & 0.18 \\
\hline LSD $g_{i}-g_{j} 5 \%$ & 0.78 & 0.83 & 0.41 & 1.59 & 1.15 & 0.70 & 0.46 & 0.36 & 0.21 \\
\hline LSD $g_{i}-g_{j} 1 \%$ & 1.04 & 1.11 & 0.53 & 2.13 & 1.54 & 0.92 & 0.61 & 0.48 & 0.28 \\
\hline
\end{tabular}


Genetic behavior of some soybean genotypes under normal and stress ......

Table (7): Cont.

\begin{tabular}{|c|c|c|c|c|c|c|c|c|c|}
\hline Traits & \multicolumn{3}{|c|}{ No. of pods /plant } & \multicolumn{3}{|c|}{100 seed weight(g) } & \multicolumn{3}{|c|}{ Seed yield/ plant (g) } \\
\hline Parent & Normal & Stress & Comb. & Normal & Stress & Comb. & Normal & Stress & Comb. \\
\hline Lkota & $-18.52^{* *}$ & $-13.37^{* *}$ & $-16.21^{* *}$ & $-0.24^{*}$ & $-0.62^{* *}$ & $-0.43^{* *}$ & $-15.36^{\star *}$ & $-15.83^{* *}$ & $-16.14^{\star *}$ \\
\hline Giza82 & $-21.11^{* *}$ & $-18.48^{* *}$ & $-21.33^{* *}$ & $-0.94^{\star *}$ & $-0.43^{* *}$ & $-0.69 * *$ & $-18.08^{* *}$ & -18.70 ** & $-18.53^{* *}$ \\
\hline D89-8940 & $11.59 * *$ & $17.63^{* *}$ & $15.52^{* *}$ & 0.08 & 0.07 & 0.07 & $7.47^{* *}$ & $11.23^{* *}$ & $9.54^{* *}$ \\
\hline Dr101 & 0.85 & $11.87^{* \star}$ & $5.99 * *$ & $-0.24^{\star *}$ & $-0.23^{* *}$ & $-0.24^{\star *}$ & 0.91 & $10.03^{* *}$ & $6.08^{* *}$ \\
\hline Line162 & $11.49 * *$ & $10.03^{* *}$ & $10.81^{* *}$ & 0.40 ** & 0.69 ** & $0.55^{* *}$ & $14.52^{* *}$ & $8.84^{* *}$ & $11.22 * *$ \\
\hline Giza21 & $15.69 * *$ & $-7.68^{\star *}$ & $5.22 * *$ & $0.94^{* *}$ & $0.53^{* *}$ & $0.73^{* *}$ & $10.54^{* *}$ & $4.43^{* *}$ & 7.83 \\
\hline LSD $g_{i} 5 \%$ & 0.98 & 1.19 & 0.52 & 0.18 & 0.14 & 0.07 & 1.09 & 1.06 & 0.52 \\
\hline LSD $g_{i} 1 \%$ & 1.31 & 1.58 & 0.69 & 0.24 & 0.19 & 0.10 & 1.45 & 1.41 & 0.68 \\
\hline LSD $g_{i}-g_{j} 5 \%$ & 1.51 & 1.83 & 0.84 & 0.27 & 0.21 & 0.12 & 1.68 & 1.63 & 0.83 \\
\hline LSD $g_{i}-g_{j} 1 \%$ & 2.02 & 2.44 & 1.10 & 0.37 & 0.29 & 0.16 & 2.24 & 2.18 & 1.09 \\
\hline
\end{tabular}

* and ** significant at 0.05 and 0.01 levels of probability, respectively.

B-3-2- Specific combining ability effects.

Specific combining ability effects Ŝij of the cross combinations computed for normal, stress and combined data for all the studied traits are presented in Table (8). For days to maturity, eight, five and seven crosses under normal, stress and the combined analysis respectively, expressed significantly negative $\hat{S} i j$ effects. The most desirable Ŝij effects were recorded by three crosses Lkota $x$ Giza21, Giza82 x Giza21 and Dr101 X Giza21. For plant height, eight, nine and seven crosses under normal, stress and the combined analysis respectively, expressed significantly positive $\hat{S} i j$ effects. The most desirable Ŝij effects were registered by five crosses Lkota $x$ D89-8940, Lkota x Dr101, Giza82 x P3 and Giza82 x Dr101. For main root length, five crosses under both irrigation treatments and the combined analysis expressed significantly positive Ŝij effects. The most desirable Ŝij effects were recorded by the cross D89-8940 x Dr101 followed by Giza82 x Dr101 and Lkota x Dr101. For number of pods/plant, ten, eleven and eleven crosses under normal, stress and the combined analysis respectively, expressed significantly positive $\hat{S} i j$ effects. The most desirable $\hat{S} i j$ effects were registered by five crosses Giza82 $x$ Giza21, D89-8940 x Line162, D89-8940 x Giza21, D89-8940 x Dr101 and Dr101 x Giza21. For 100-seed weight only the five crosses Lkota x Giza82, Lkota x Giza21, Giza82 x Dr101, Dr101 x Line162 and Line162 $x$ Giza21 showed positive desirable Ŝij effects for this traits in both irrigation treatments and the combined analysis. For seed yield / plant (g) eleven, eight and twelve crosses under normal, stress and the combined analysis, respectively showed significantly positive Sij effects. The most desirable Sij effects were recorded by the cross Dr101 x Line162 flowed by Lkota x Dr101 and Dr101 x Giza21.

The previous results were in harmonic with those by El-Shaboury et al., (2006), Perez et al., (2009) and Waly (2015). 
Table (8): Estimates of sca effects (Ŝij) for individual cross for each trait of normal, stress and the combined data.

\begin{tabular}{|c|c|c|c|c|c|c|c|c|c|}
\hline \multirow{2}{*}{ Crosses } & \multicolumn{3}{|c|}{ Maturity date (day) } & \multicolumn{3}{|c|}{ plant height $(\mathrm{cm})$} & \multicolumn{3}{|c|}{ main root length $(\mathrm{cm})$} \\
\hline & Normal & Stress & Comb. & Normal & Stress & Comb. & Normal & Stress & Comb. \\
\hline Lkota x Giza82 & $-3.62^{\star *}$ & $-10.13^{\star *}$ & $-6.87^{* *}$ & -1.33 & $-21.55^{\star \star}$ & $-11.44^{\star *}$ & $-1.79^{* *}$ & $-2.2^{\star \star}$ & $-1.99^{\star \star}$ \\
\hline Lkota x D89-8940 & $10.64^{\star *}$ & $11.74^{\star \star}$ & $11.19^{* *}$ & $15.56^{* \star}$ & $27.5^{\star \star}$ & $21.53^{* *}$ & $2.72^{* *}$ & $2.92^{\star *}$ & $2.82^{\star \star}$ \\
\hline Lkota x Dr101 & 0.43 & 0.48 & 0.46 & $17.43^{\star \star}$ & $23.22^{\star \star}$ & $20.33^{\star *}$ & $3.46^{* *}$ & $3.29^{\star \star}$ & $3.37^{\star \star}$ \\
\hline Lkota x Line162 & $-4.57^{\star *}$ & 0.74 & $-2.25^{\star \star}$ & -2.53 & $-6.34^{\star \star}$ & $-4.44^{\star *}$ & -0.74 & $-1.14^{*}$ & $-0.94^{\star}$ \\
\hline Lkota x Giza21 & $-9.4^{\star \star}$ & $-8.26^{\star \star}$ & $-8.83^{\star *}$ & $25.38^{\star *}$ & $-4.35^{\star \star}$ & $10.86^{* *}$ & -0.72 & $-1.56^{* *}$ & $-1.14^{\star \star}$ \\
\hline Giza82 x D89-8940 & $2.26^{\star \star}$ & 1.54 & $1.90^{\star \star}$ & $19.20^{* *}$ & $25.36^{* *}$ & $22.28^{* *}$ & $1.34^{*}$ & $4.54^{* *}$ & $2.94^{* *}$ \\
\hline Giza82 x Dr101 & $16.72^{\star *}$ & $17.02^{\star *}$ & $16.87^{* *}$ & $23.53^{* *}$ & $19.89^{* *}$ & $21.71^{\star *}$ & $3.24^{\star *}$ & $4.08^{* *}$ & $3.66^{\star \star}$ \\
\hline Giza82 x Line162 & 0.74 & -1.7 & -0.82 & -2.03 & $2.41^{*}$ & 0.53 & 1.03 & -0.65 & 0.53 \\
\hline Giza82 x Giza21 & $-11.77^{\star *}$ & $-5.77^{\star *}$ & $-8.77^{\star *}$ & $-11.16^{\star *}$ & 0.93 & $-5.46^{\star *}$ & $1.31^{*}$ & $-1.77^{* *}$ & -0.57 \\
\hline D89-8940 x Dr101 & $-1.71^{*}$ & 0.50 & -0.94 & $4.94^{\star \star}$ & $2.39^{*}$ & 3.67 & $6.47^{\star *}$ & $6.95^{\star *}$ & $6.71^{\star \star}$ \\
\hline D89-8940 x Line162 & $-4.02^{\star *}$ & 0.49 & $-2.11^{\star \star}$ & $-15.82^{\star \star}$ & -18.71 & $-17.26^{\star \star}$ & $-1.39^{*}$ & $-4.68^{\star *}$ & $-3.04^{\star \star}$ \\
\hline D89-8940 x Giza21 & 0.82 & $2.66^{\star *}$ & $1.74^{\star \star}$ & $6.86^{\star \star}$ & $2.76^{*}$ & $4.81^{\star \star}$ & $-1.77^{* *}$ & $-3.60^{\star *}$ & $-2.69^{\star \star}$ \\
\hline Dr101 x Line162 & $-1.90^{* *}$ & $-3.14^{\star *}$ & $-2.52^{\star \star}$ & 2.4 & $-5.05^{\star *}$ & -1.67 & 0.96 & 0.64 & 0.8 \\
\hline Dr101 x Giza21 & $-10.07^{\star *}$ & $-7.60^{\star *}$ & $-8.84^{\star *}$ & $16.73^{\star *}$ & $13.82^{\star *}$ & $15.27^{* *}$ & $-1.64^{\star *}$ & $2.65^{\star *}$ & $0.85^{\star \star}$ \\
\hline Line162 x Giza21 & $17.16^{\star \star}$ & $12.1^{* *}$ & $14.63^{\star \star}$ & $-7.93^{* \star}$ & $2.54^{*}$ & $-3.04^{\star *}$ & $1.46^{* \star}$ & $1.93^{\star *}$ & $1.70^{\star \star}$ \\
\hline LSD Sij 5\% & 1.69 & 1.78 & 1.31 & 3.13 & 2.35 & 2.03 & 1.13 & 0.95 & 0.83 \\
\hline LSD Sij 1\% & 2.14 & 2.27 & 1.63 & 4.07 & 3.03 & 2.59 & 1.39 & 1.15 & 0.99 \\
\hline LSD sij-sik 5\% & 2.35 & 2.5 & 1.79 & 4.5 & 3.34 & 2.87 & 1.51 & 1.24 & 1.07 \\
\hline LSD sij-sik 1\% & 3.03 & 3.22 & 2.26 & 5.91 & 4.35 & 3.69 & 1.91 & 1.55 & 1.31 \\
\hline LSD sij-skI 5\% & 2.2 & 2.34 & 0.89 & 4.19 & 3.12 & 1.29 & 1.43 & 1.18 & 0.62 \\
\hline LSD sij-skl 1\% & 2.83 & 3.01 & 1.07 & 5.5 & 4.06 & 1.61 & 1.79 & 1.46 & 0.71 \\
\hline
\end{tabular}

Table (8): Cont.

\begin{tabular}{|c|c|c|c|c|c|c|c|c|c|}
\hline \multirow{2}{*}{ Crosses } & \multicolumn{3}{|c|}{ No. of pods /plant } & \multicolumn{3}{|c|}{100 seed weight(g) } & \multicolumn{3}{|c|}{ Seed yield/ plant (g) } \\
\hline & Normal & Stress & Comb. & Normal & Stress & Comb. & Normal & Stress & Comb. \\
\hline Lkota x Giza82 & $21.94^{\star *}$ & $14.55^{\star *}$ & $18.24^{* *}$ & $1.78^{\star *}$ & $1.76^{* *}$ & $1.77^{\star *}$ & $13.73^{\star *}$ & $2.78^{\star *}$ & $8.26^{* *}$ \\
\hline Lkota x D89-8940 & $17.82^{\star \star}$ & $15.36^{\star *}$ & $16.59^{* *}$ & $-1.36^{\star *}$ & $-0.49^{*}$ & $-0.93^{* *}$ & $7.37^{\star *}$ & $16.60^{\star *}$ & $11.99^{\star *}$ \\
\hline Lkota x Dr101 & $21.58^{* *}$ & $18.05^{\star *}$ & $19.82^{\star *}$ & 0.20 & 0.26 & 0.23 & $24.21^{\star *}$ & $24.55^{\star *}$ & $24.38^{\star *}$ \\
\hline Lkota x Line162 & $3.04^{*}$ & $4.66^{\star *}$ & $3.85^{\star *}$ & $-1.17^{\star *}$ & $-0.64^{\star \star}$ & $-0.90^{\star *}$ & $9.19^{\star *}$ & 0.94 & $5.07^{\star *}$ \\
\hline Lkota x Giza21 & $-20.90^{\star *}$ & -0.44 & $-10.67^{\star *}$ & $1.20^{\star \star}$ & $1.70^{\star \star}$ & $1.45^{\star \star}$ & 1.67 & 1.66 & 1.66 \\
\hline Giza82 x D89-8940 & $-32.08^{\star *}$ & $-29.23^{\star *}$ & $-30.66^{\star *}$ & 0.46 & -0.26 & 0.10 & 2.77 & $9.02^{\star *}$ & $5.90^{* *}$ \\
\hline Giza82 x Dr101 & -1.34 & -1.31 & -1.32 & $0.58^{*}$ & $0.92^{\star \star}$ & $0.75^{\star \star}$ & -1.22 & 2.82 & 1.14 \\
\hline Giza82 x Line162 & $-4.99^{\star *}$ & $-10.67^{* *}$ & $-7.83^{\star *}$ & $-1.14^{\star *}$ & $-0.74^{* *}$ & $-0.94^{* *}$ & $-7.03^{* *}$ & 1.52 & $-3.10^{\star *}$ \\
\hline Giza82 x Giza21 & $37.34^{\star *}$ & $38.11^{* *}$ & $37.72^{\star *}$ & $-0.98^{\star *}$ & $-0.87^{* *}$ & $-0.92^{* *}$ & $19.32^{\star *}$ & $4.42^{* *}$ & $11.87^{\star *}$ \\
\hline D89-8940 x Dr101 & $22.80^{* *}$ & $20.3^{\star *}$ & $21.55^{\star *}$ & 0.44 & 0.15 & 0.30 & $7.72^{\star \star}$ & $8.14^{\star *}$ & $7.93^{\star \star}$ \\
\hline D89-8940 x Line162 & $23.00^{* *}$ & $26.83^{* *}$ & $24.92^{* *}$ & 0.08 & $-1.06^{* *}$ & $-0.49^{* *}$ & $15.43^{* *}$ & $20.29^{* *}$ & $17.86^{\star *}$ \\
\hline D89-8940 x Giza21 & $20.01^{* *}$ & $43.08^{* *}$ & $31.55^{\star *}$ & 0.07 & $-1.52^{\star *}$ & $-0.72^{* *}$ & 12.96 ** & $3.97^{*}$ & $8.46^{\star \star}$ \\
\hline Dr101 x Line162 & 2.28 & $5.26^{\star *}$ & $3.77^{\star *}$ & $1.40^{\star *}$ & $1.59^{\star \star}$ & $1.50^{\star \star}$ & $25.00^{* *}$ & $26.31^{\star *}$ & $25.65^{\star \star}$ \\
\hline Dr101 x Giza21 & $23.51^{\star *}$ & $46.77^{\star *}$ & $35.14^{\star *}$ & $-1.10^{* *}$ & -0.16 & $-0.63^{\star *}$ & $20.05^{\star *}$ & $29.84^{\star *}$ & $24.94^{\star *}$ \\
\hline Line162 x Giza21 & $19.26^{\star *}$ & $19.49^{\star *}$ & $19.37^{* *}$ & $0.67^{\star \star}$ & $0.82^{\star \star}$ & $0.74^{\star \star}$ & $9.21^{\star \star}$ & -1.55 & $4.17^{\star *}$ \\
\hline LSD Sij 5\% & 2.99 & 3.55 & 2.39 & 0.49 & 0.38 & 0.30 & 3.28 & 3.2 & 2.36 \\
\hline LSD Sij 1\% & 3.89 & 63 & 3.06 & 0.65 & 0.51 & 0.40 & 4.27 & 4.17 & 3.02 \\
\hline LSD sij-sik 5\% & 4.29 & 5.13 & 3.4 & 0.73 & 0.57 & 0.45 & 4.73 & 4.61 & 3.35 \\
\hline LSD sij-sik 1\% & 5.63 & 6.75 & 4.4 & 0.97 & 0.76 & 0.60 & 6.21 & 4.97 & 4.34 \\
\hline LSD sij-skl 5\% & 4 & 4.77 & 1.5 & 0.67 & 0.52 & 0.17 & 4.4 & 4.29 & 4.69 \\
\hline LSD sij-skI 1\% & 5.24 & 6.27 & 1.87 & 0.90 & 0.70 & 0.23 & 5.78 & 5.63 & 5.11 \\
\hline
\end{tabular}

* and ${ }^{* *}$ significant at 0.05 and 0.01 levels of probability, respectively. 


\section{REFERENCES}

Abass, S. M. and H. I. Mohamed (2011). Alleviation of adverse effects of drought stress on common bean (Phaseolus vulgaris L.) by exogenous application of hydrogen peroxide. Bangladesh J. Bot. 41: 75-83.

Abdalla, M.M. (2011). Beneficial effects of diatomite on the growth, the biochemical contents and polymorphic DNA inLupinus albusplants grown under water stress. Agriculture and Biology Journal of North America 2: 207-220.

Abdelgawad, Z.A., T.R. Mohamed, S. Afiah and H. Al-Agwany (2015). Effect of drought and salt stress on growth, osmolytes, protein, and isozymes in Vicia faba genotypes. Egy. J. of Agron. 37: 93-119.

Agrawal, A.P., P.M. Salimath and S.A. Patil (2005). Gene action and combining ability analysis in soybean \{Glycine $\max$ (L.) Merrill\}. Legume Res. 28 (1): 7-11.

Aminifar, J., G. Mohsenabadi, M. H. Biglouei and H. Samiezadeh (2013). Selection of soybean tolerant cultivars based on drought tolerance indices under deficit irrigation conditions. International Journal of Pure Scientific Researches., 1 (1): 12-15.

Ashraf, M. (2010). Inducing drought tolerance in plants: recent advances. Biotechnol. Adv. 28: 169183.

Azadeh, R., F. Maryam and S. Saeed (2014). The effects of seed priming by ascorbic acid on some morphological and biochemical aspects of rapeseed (Brassica napusL.) under drought stress condition. Int. J. Biosci. 4 (1): 432-442.

Bates, L., R.P. Waldren and I.D. Teare (1973). Rapid determination of free proline for water-stress studies. Plant and Soil, 39: 205-207.
Desclaux, D., T.T. Huynh and P. Roumet (2000). Identification of soybean plant characteristics that indicate the timing of drought stress. Crop Science; 40(3): 716-722.

Durai, A.A. and B. Subbalakshmi (2010). Heterosis and combining ability in soybean for the traits of vegetable importance. Veg. Sci. 37(1): 48-51.

El-Garhy, A. M., M. Shaaban, Ola A. M. EL-Galaly, M. M. Omran, E. H. El-Harty and S. B. Ragheb (2008). Combining ability and heterosis in some top crosses of soybean (Glycine max (L) merrill). Annals of Agric. Sci.,Moshtohor, 46(1):45-53.

El-Shaboury, Hoda M. G., Soheir A. Zein El-Abdien, S. A. Attia and M. Shaaban (2006). Heterosis and combining ability for yield and its components in soybean top crosses. J. Adv. Agric. Res., 11(1): 11-22.

FAOSTAT (2019). Food and Agriculture Organization of The United Nation.

Farshadfar, E., Z. Kazemi and A. Yaghotipoor (2013). Estimation of combining ability and gene action for agro-morphological characters of rapeseed (Brassica napus L.) using linextester mating design. Int J. Adv. Biol Biom. Res. 1 (7): 711-717.

Fehr, W.R. (1987). Principles of cultivar development. Vol.1. theory and technique. Macmillan Publ. Co. New York. NY. 536p.

Frederick, J.R., C.R. Camp and P.J. Bauer (2001). Drought-stress effects on branch and main stem seed yield and yield components of determinate soybean. Crop Science 41(3): 759-763.

Griffing, B. (1956). Concept of general and specific combining ability in relation to diallel crossing system. Aust. J. Biol. Sci. 9: 463-493. 
Hayes, H.K. and F.R. Immer (1942). Methods of plant breeding. Mc Graw Hill Book Co., Inc. New York, NY.

Heba, I. M. and A. A. Shamia (2014). Influence of garlic extract on emzymatic and non-enzymatic antioxidants in soybean plants (Glycine Max) grown under drought stress. Life Scie. J. 11:47-58.

Iqbal, M.M., Din R. Noshin and S.J. Khan (2003). Use of diallel analysis to examine the mode of inheritance of agronomic and quality parameters in F1 generation of brown mustard (Brassica juncea L. Czern and Coss). Asian J. PI. Sci. 2(14): 1040-1046.

Kim, T. H., B.R. Lee, W.J. Jung, K.Y. Kim, J.C. Avice and A. Ourry (2004). De novo protein synthesis in relation to ammonia and proline accumulation in water stressed white clover. Functional Plant Biology 31: 847-855.

Kobraei, S., A. Etminan, R. Mohammadi and S. Kobraee (2011). Effects of drought stress on yield and yield components of soybean. Annals of Biological Research, 2 (5) :504-509.

Kumar, A. and K. Sharma (2010). Leaf water content- a simple indicator of drought tolerance in crop plants. Indian J. of Agric. Scie.80: 1095- 1097.

Kumar, J. and S. Abbo (2001). Genetics of flowering time in chickpea and its bearing on productivity in the semiarid environments, Adv. Agron. 72: 107-138.

Lichtenthaler, H.K. and A.R. Wellburn (1983). Determination of Total Carotenoids and Chlorophylls $\mathbf{a}$ and $\mathbf{b}$ of Leaf Extracts in Different Solvents. Biochemical Society Transactions, 11: 591-603.

Li-Juan, Q. and C. Ru-Zhen (2010). The Origin and History of Soybean. In: B Singh, (Ed. ). The Soybean: Botany, Production and Uses. CAB
International, Oxfordshire, UK, p. 0123.

Lisar, S.Y.S., R. Motafakkerazad, M.M. Hossain and I.M.M. Rahman (2012). Water Stress in Plants: Causes, Effects and Responses. In: Rahman, I. M. M. \& Hasegawa, H. Water Stress, InTech, Croatia, p. 01-14.

Liu, Y., J.Y. Gai, H.N. Lu, Y.J. Wang and S.Y. Chen (2005). Identification of drought tolerant germplasm and inheritance and QTL mapping of related root traits in soybean (Glycine $\max ($ (L.) Merr.). Acta Genetica Sinica; 32(8): 855-863.

Machikowa. T., C. Saetang and K. Funpeng (2011). General and specific combining ability for quantitative characters in sunflower. J. Agric. Sci. 3 (1) : 91-95.

Masoumi, H., M. Masoumi, F. Darvish, J. Daneshian, G. Nourmohammadi and D. Habibi (2010). Change in several antioxidant enzymes activity and seed yield by water deficit stress in soybean (Glycine max L.) cultivars. Notulae Botanicae Horti Agrobotanici Cluj-Napoca, 38(3): 86-94.

Nazarli, H. and F. Faraji (2011). Response of proline, soluble sugars and antioxidant enzymes in wheat (Triticum aestivum L.) to different irrigation regimes in greenhouse condition. Cercetări Agronomice în Moldova XLIV ; 4: 28-5.

Perez, P.T. ; S. Clanzio and R.G. Palmer (2009). Evaluation of Soybean [Glycine max (L.) Merr.] FI hybrids Journal of Crop Improvement., 23: 1-18.

Sadeghipour, O. and S. Abbasi (2012). Soybean response to drought and seed inoculation. World Applied Sciences Journal 17(1): 55-60.

Shiv, D., P.R. Sharma, K.N. Singh and K. Mukul (2011). Combining ability analysis for yield and other quantitative traits in soybean (Glycine 
$\max$ L. Merril). Indian J. Plant Genet. Resour. 24 (3): 353-355.

Silvente, S., A.P. Sobolev and M. Lara (2012). Metabolite adjustments in drought tolerant and sensitive soybean genotypes in response to water stress. PLoS ONE, 7(6) e38554.

Singh, G. and B.G. Shivakumar (2010). The role of soybean in agriculture. In: B Singh, (Ed.). The Soybean: Botany, Production and Uses. CAB International, Oxfordshire, UK, pp. 2447.

Specht, J.E., K. Chase, M. Macrander, G.L. Graef, J. Chung, J.P. Markwell, M. Germann, J.H. Orf and K.G. Lark (2001). Soybean response to water. A QTL analysis of drought tolerance. Crop Sci., 41: 493-509.

Tan, A.S. (2010). Study on the determination of combining abilities of inbred lines for hybrid breeding using line $x$ tester analysis in sunflower (Helianthus annuu L.). HELIA. 33 (53): 131-148.

Waly, F. E. A. (2015). Breeding studies for drought tolerance in soybean using diallel crosses. PhD. Thesis, In Agric. Sci. Agron. (Crop Breeding) Fac. of Agric. Benha Univ. Egypt.

Zhang, M., L. Duan, X. Tian, Z. He, J.Li, B. Wang and Z. Li (2007). Uniconazoleinduced tolerance of soybean to water deficit stress in relation to changes in photosynthesis, hormones and antioxidant system. J Plant Physiol. 164: 709-717.

Zhang, M., L. Duan, Z. Zhai, J. Li, X. Tian, B. Wang, Z. He and Z. Li (2004). Effects of plant growth regulators on water deficit-induced yield loss in soybean. Proceedings of the $4^{\text {th }}$ International Crop Science Congress, Brisbane, Australia. 
السلوك الوراثى لبعض التراكيب الوراثية من فول الصويا تحت ظروف الرى الطبيعى ونقص مياه الرى

\author{
فايز السيد عبد الرازق والىى \\ قسم بحوث المحاصيل البقولية - معهل بحوث المحاصيل الحقلية - مركز البحوث الزراعية - الجيزة - مصر.

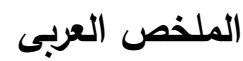

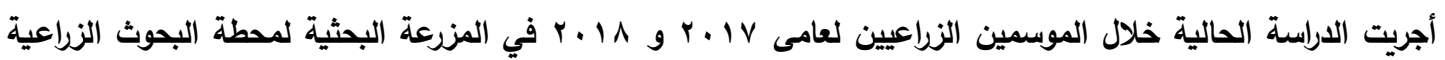

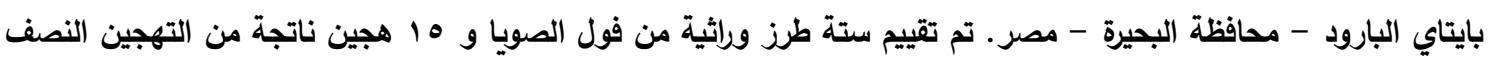
دائرى بينها فى الجيل الأول لصفات محصول البذور وبعض صفاتها تحت الري العادي (ري كل ه 1 يومًا) و نقص الرى (ري كل

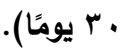

و كان الهذف من الاراسة:

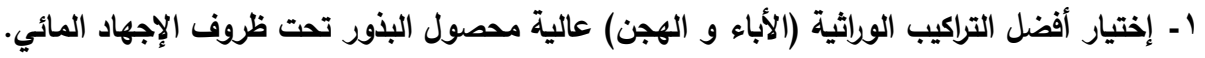

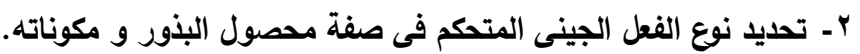

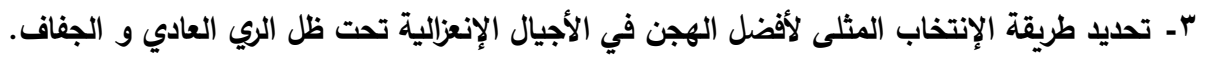
و كانت نتائج الاراسة على النحو التالى:

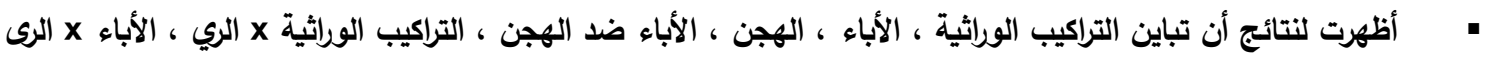
، الهجن x الري و الأباء x الري كان معنويا لكل الصفات المدروسة تحت كل من معاملات الري والتحليل

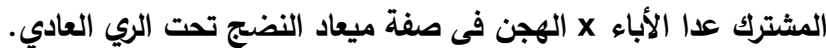

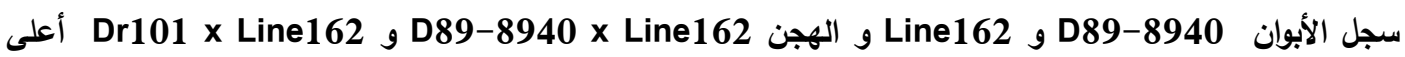
إنتاجية للنبات / النبات (g) في كل من معاملتى الري وإلتحليل المشترك. أوضحت النتائج أن التباين الراجع للقدة العامة على التألف (GCA) والقدرة الخاصة على التألف (SCA)كان معنوياً

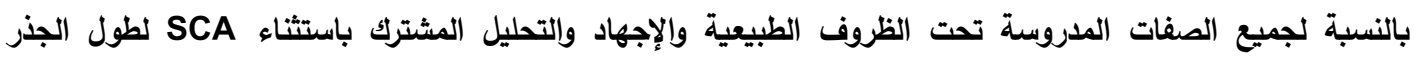
الرئيسي تحت الري العادي.

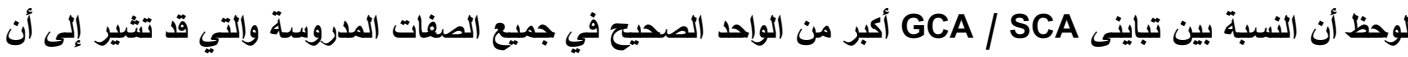
الجزء الأكبر من التباين المرتبط بهذه الصفات ناتج عن الفعل الجينى المضيف و المضيف x المضيف.

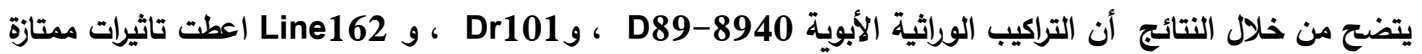
للقدرة العامة على التألف لصفة محصول البذور / النبات ومعظم الصفات الأخرى تحت الرى الطبيعي والإجهاد والتحليل المشترك.

تم تسجيل أفضل تأثيرات للقدرة الخاصة على التألف لصفة محصول البذور / النبات بواسطة الهجن Dr101 x Dr101 x Giza21 و Lkota x Dr101 تلاه Line162 تعتبر طريقة سجلات النسب طريقة ممتازة في هذه الدراسة لاختيار أفضل الهجن فى الأجيال الإنعزالية ذات محصول عالى في ظروف الرى الطبيعى والجفاف. أسماء السادة المحكمين أ.د / أمجد عبدالغفار الجمال كلية الزراعة - جامعة طنطا

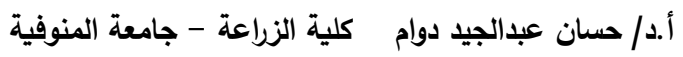

